\title{
Behavior of silver nanotextiles during washing
}

\section{Master Thesis}

Author(s):

Geranio, Luca

Publication date:

2009

Permanent link:

https://doi.org/10.3929/ethz-a-005883580

Rights / license:

In Copyright - Non-Commercial Use Permitted 


\section{EH}

Eidgenössische Technische Hochschule Zürich

Swiss Federal Institute of Technology Zurich

\section{EMPA *}

Materials Science \& Technology

\section{Master thesis}

\section{Behavior of Silver Nanotextiles}

\section{during Washing}
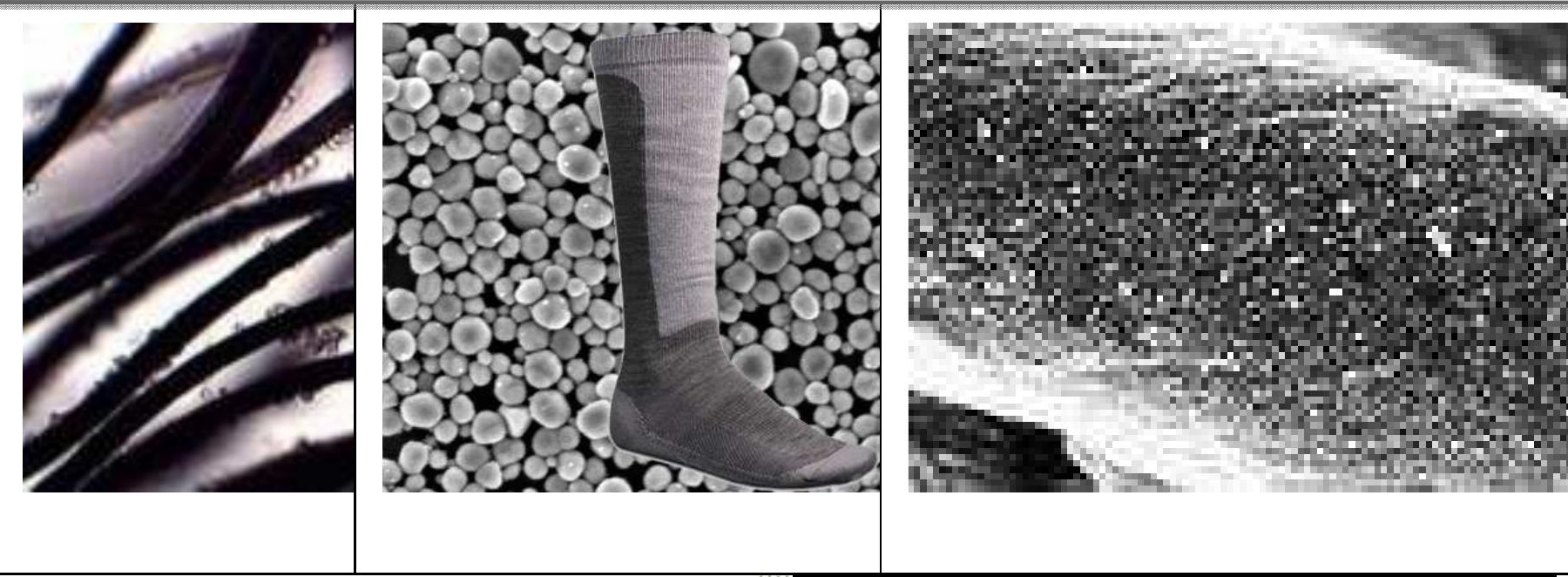

Author: Luca Geranio

Supervisors: PD Dr. Bernd Nowack

Dr. Manfred Heuberger

[May 2009] 


\section{Author:}

Luca Geranio

agerani@tele2.it

\section{Cover pictures:}

www.engadget.com/.../

http://www.gizmodo.com.au/2008/11/nano_silver_may_be_envionments_silver_bullet-2.html www.news.cornell.edu/.../May07/nanoparticle.jpg 


\section{Content}

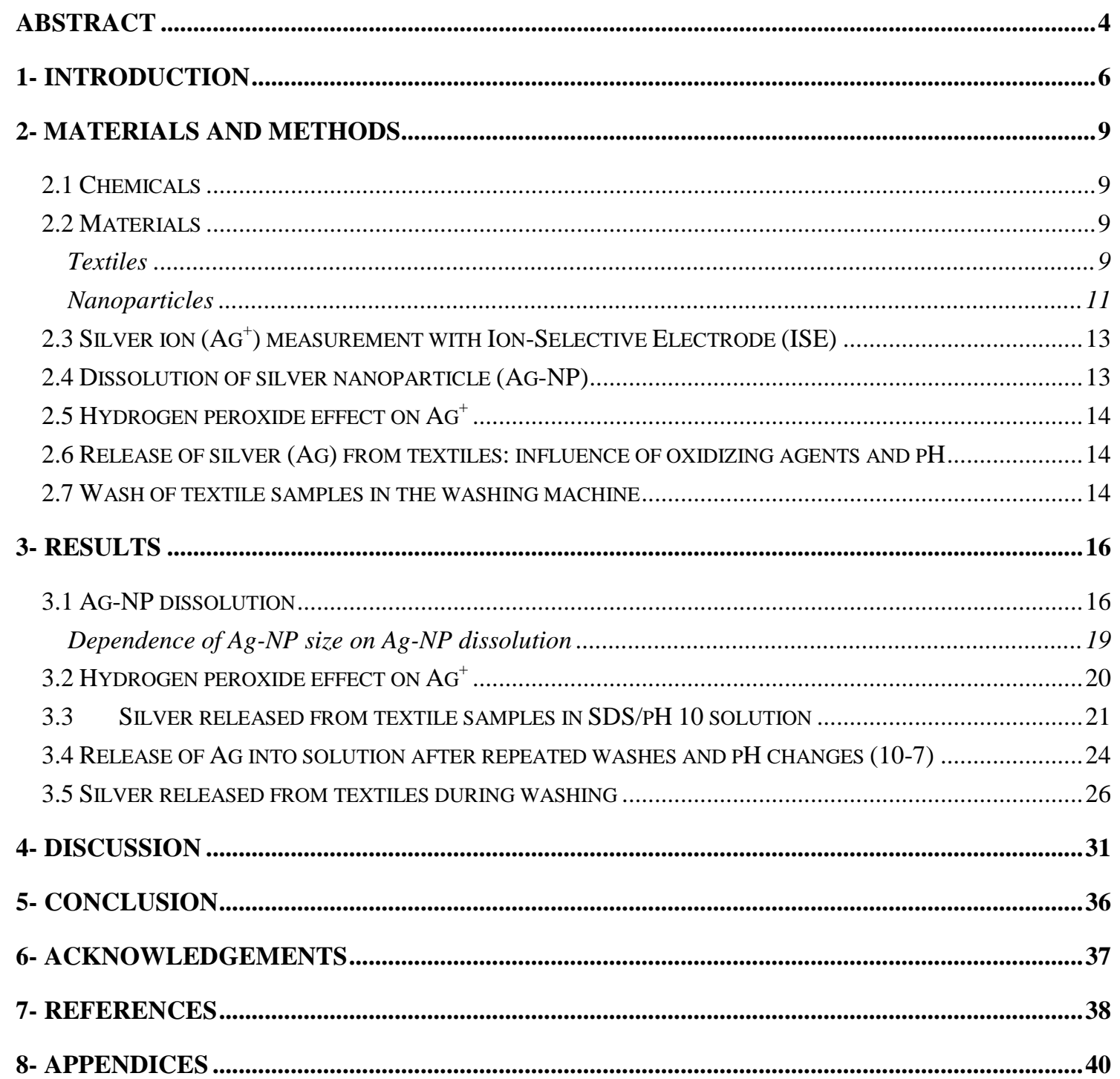




\section{Abstract}

The incorporation of silver nanoparticles (Ag-NPs) in fabrics, as anti-bacterial and fungal agent, has become a flourishing technology. On the other hand, little is known about the consequences of the nano-Ag release from these nanomaterials into the environment. The amount and the form of silver leached from textiles are the fundamental information needed for predicting the environmental risk posed by the spread of these nano-Ag products. This paper investigates the silver $(\mathrm{Ag})$ released from various nano-Ag-fabrics and commercial textiles during washing. In a first step, the dissolution of Ag-NPs at pH 7 and 10 and the release of the silver cation $\left(\mathrm{Ag}^{+}\right)$was studied over time. The influence of oxidizing compounds such hydrogen peroxide and peracetic acid (PAA), as well as bleaching agents (perborate) and bleach activators (TAED, tetraacetylethylenediamine) on nanoparticle dissolution was examined. In a second step fabrics with different $\mathrm{Ag}$ and nano- $\mathrm{Ag}$ incorporation were immersed in a $\mathrm{pH} 10$ solution for $\sim 4$ hours and the total and dissolved Ag released was quantified. In the third step the textile samples were washed in the washing machine applying standardized conditions.

PAA and the combination of Perborate/TAED (at $40^{\circ} \mathrm{C}$ ) dissolved the Ag-NPs very rapidly at $\mathrm{pH}$ 10: the $\mathrm{Ag}^{+}$concentration increased by a factor of $\sim 1500$ and $\sim 720$ respectively over 1 hour. This huge dissolution was not observed in the experiments with textiles, revealing the scavenging action of the reactive species by the fiber itself and the inhibited access of the oxidants to the silver. Ag-NPs with smaller size and consequently larger surface, were oxidized to a greater extent by the oxidant (hydrogen peroxide) at $\mathrm{pH} 10$ than larger particles.

Almost all the textiles leached $0-15 \%$ of their total Ag content after 150 minutes under gentle stirring conditions at $\mathrm{pH} 10$. Only one sample displayed a larger release of up to $27 \%$ of the textile $\mathrm{Ag}$ content. For two out of the nine fabric samples $\mathrm{Ag}^{+}$was the prevalent $(>80 \%)$ form in solution. In the other textiles, except one, Ag in the coarse-grained fraction (particles larger than $0.45 \mu \mathrm{m}$ ) varied from $\sim 29$ to $100 \%$ of the total Ag released.

In the washing machine trials the silver released in the $>0.45 \mu \mathrm{m}$ fraction represents at least $50 \%$ (generally $>80 \%$ ) of the total silver released in the washing liquor. The mechanical stress applied in the washing machine cycle thus played a relevant role. Generally the percentage of the total silver content emitted from the textiles varied consistently among products (from less than $1 \%$ to $45 \%$ ). For four out of six fabrics tested, the addition of the bleach increased the total silver leached in the detergent liquor, although the silver containing size-classes did not seem to change considerably. Dissolved silver was measured in four out of eight fabrics tested. All the textile samples in the washing machine seem to release silver at lower rate in the second wash. The conventional Ag-textile (X-Static fabric) did not show big differences in the behavior compared to the nano-textiles during washing in the washing machine. 
A decrease of the free $\mathrm{Ag}^{+}$concentration was observed at $\mathrm{pH} 10$ after the addition of $\mathrm{H}_{2} \mathrm{O}_{2}$ (in absence of Ag-NPs). 


\section{1- Introduction}

Nanotechnology has rapidly thrived in the last years. The use of silver nanoparticles (Ag-NPs) in commercial products is proliferating essentially for the anti-bacterial, fungicidal properties of silver. According to the Woodrow Wilson Institute more than 230 declared products containing Ag-NP are currently on sale [1]. Among these: cosmetics, sprays, cloths, textile, food preparation equipment, food storage containers, medical devices, dressing for wounds and paints. Some market analysts predicts a growth to up to 110-230 tons of silver per year in the European Union by 2010 [2]. This surge of nanomaterials output that can release silver in both ionic and particulate form has drawn attention on the possible health risk for the environment [2][1]. Although studies displayed the inhibition of growth in numerous microorganisms by AgNPs, the mechanism of toxicity has not been elucidated clearly [3-6].

The $\mathrm{Ag}^{+}$ion is well-known since a long time to be highly detrimental for aquatic organisms and bacteria [7]. Navarro et al. showed its toxicity toward the photosynthesis of Chlamydomonas reinhardtii algae with an $\mathrm{EC50}(1 \mathrm{~h})$ of $188 \pm 61 \mathrm{nM}$ [8]. As shown in the study, the release of $\mathrm{Ag}^{+}$ from the Ag-NPs could imply a direct interaction between the nanoparticles and the microorganism [8][9]. Although $\mathrm{Ag}^{+}$occurs in low concentration in the environment, little is known about the toxicity of organic and inorganic silver sulphide compounds which are the most environmental considerable species [2]. The United States Environmental Protection fixed the water quality criteria values of silver ionic concentration in salt and fresh water at 1.9 and 3.4 $\mathrm{ppb}$, respectively. The positively charged ionic form of silver has a high affinity for negatively charged side groups on biological molecules such as proteins and nucleic acids. The bond of $\mathrm{Ag}^{+}$to the bacterial cell surface components alters the molecular structure interrupting respiration and adenosine triphosphate (ATP) synthesis [10]. The simultaneous attacks of various sites within cell disrupt critical physiological functions of the bacteria such as membrane transport, protein folding and function, electron transport, DNA transcription and cell-wall synthesis [11].

The widespread diffusion of Ag-nanoproducts could be explained by the possibility of placing the Ag-NP onto or into products where it was not doable before (e.g. the lining of medical devices). In such locations the $\mathrm{Ag}^{+}$can be delivered and exert the disinfection function [12]. Another plus is the size of particles in the nano-scale which enables to release $\mathrm{Ag}^{+}$faster compared to larger nanoparticles with less specific surface area [13].

Recently the incorporation of Ag-NP in textiles (e.g. in socks, slippers, shoe liners, outwear and sportswear, bedding materials) got a common practice. In these products, the oxidation of nanoparticles $\left(\mathrm{Ag} 9\right.$ in contact with water causes a long term release of $\mathrm{Ag}^{+}$ions that is exploited for bactericidal, anti-odor purposes [10]. Given the diffusion and the frequent household washes 
of these materials, it is conceivable to expect an increase of the $\mathrm{Ag}$ concentration in wastewaters. Blaser et al claim that the majority of $\mathrm{Ag}$ will be retained into sewage sludge of waste water treatment plant (WWTP) [2, 7]. Nonetheless this amount is also re-introduced into the environment via agricultural land applications. Benn et al. state that for an influent silver concentration of $180 \mu \mathrm{g} / \mathrm{L}$ (5 $\mu \mathrm{g} / \mathrm{L}$ is the common municipal WWTP silver conc.), the $\mathrm{Ag}$ concentration in the biosolid would be above the maximum contamination levels (MCLs) set by USEPA [14]. Therefore an increase in the use of silver containing products would impede the exportation of the sewage sludge (employed as fertilizer) from waste water treatment plants (WWTPs) to agricultural lands [14]. Indeed, if the load of Ag in the incoming wastewater will step up, it is likely that more Ag will also by-pass the wastewater treatment. Furthermore the Ag-NP removal efficiency in WWTPs has not been studied yet [14].

Blaser et al. predicted that in 2010 up to $15 \%$ of the total silver released into water in European Union will come from biocidal plastics and textile [2]. Unfortunately, precise estimations of emissions from nano-materials are hampered by the lack or frequent inconsistent available information about the content and the form of $\mathrm{Ag}$ in the products. Lately Mueller and Nowack modeled the amounts of engineered Ag nanoparticles released into environment from a lifecycle perspective. In the realistic scenario, they predicted an environmental concentration of $\mathrm{Ag}$ NPs in water equal to $0.03 \mu \mathrm{g} \mathrm{L}^{-1}$. Besides they affirmed that the production volume of AgNPs would need to increase 100 times in order to have a risk quotient (PEC/PNEC, predicted environmental concentration/predicted no effect concentration) around 1. However the analysis did not include the hazard posed by the ionic silver. Thus they concluded that the release of silver in the ionic form from AgNPs is of a greater importance compared to the release of AgNPs itself [15]. Recently Benn et al. [14] quantified the leaching of Ag-NP from six brands of socks into distilled water and studied the adsorption of $\mathrm{Ag}$ (nanoparticle or ionic) on wastewater biomass. In that study, the cloths were immersed in ultrapure or tap water under shaking condition for 1 hour or alternatively 24 hours. At least three consecutive washes were conducted and the Ag was size fractionated. Moreover the presence and size of Ag-NPs in the socks was checked through SEM analysis. The wash solutions were also characterized by ion selective electrode measurements for ionic Ag and by TEM/EDX analysis for colloidal form of silver. Nonetheless the influence of detergents and the mechanical stress during washing on silver released was not covered by that research. In addition, the use of bleaching agents and the effect of the higher basicity (generally $\mathrm{pH}$ around 10 or more) of the washing liquor, compared to distilled or tap water, were not considered. These factors are decisive in representing the "real" washing conditions.

So far there are no studies about the Ag-release from textile during the washing machine run. An important parameter for modeling and predicting more precisely the Ag concentration in the environment is the quantification and characterization of Ag leached from Nano-Ag-products. 
This thesis investigated the behavior of various silver containing fabrics during washing. The quantity and the form of $\mathrm{Ag}$ (particulate or ionic) released into the washing solution was determined in two kind of experiments. In the first one the textile samples were immersed in a $\mathrm{pH} 10$ solution for $\sim 4$ hours, in the second one they were washed in the washing machine for 30 minutes, at $40{ }^{\circ} \mathrm{C}$, applying mechanical stress. $\mathrm{F}$ urthermore the influence of $\mathrm{pH}$, surfactants, oxidizing agents (present during washing), and nanoparticle-size on Ag-NP dissolution was evaluated. 


\section{2- Materials and Methods}

\subsection{Chemicals}

The buffer 3-Morpholino propane sulfonic acid ( MOPS, $\mathrm{C}_{7} \mathrm{H}_{15} \mathrm{NO}_{4} \mathrm{~S}$; $\geq 99,5 \%$ ) was purchased from SIGMA. Sodium nitrate $\left(\mathrm{NaNO}_{3}\right)$ was obtained from Riedel de Haën. Sodium carbonate decahydrate $\left(\mathrm{Na}_{2} \mathrm{CO}_{3} .10 \mathrm{H}_{2} \mathrm{O}, \geq 99 \%\right)$, n- dodecylsulfat sodium salt ( $\mathrm{SDS}, \mathrm{C}_{12} \mathrm{H}_{25} \mathrm{NaO}_{4}, \geq 99 \%$ ), sodium cloride ( $\mathrm{NaCl} \geq 99,5 \%), \mathrm{N}, \mathrm{N}^{\prime} \mathrm{N}^{\prime}, \mathrm{N}^{\prime}$ - Tetraacetylethylenediamine (TAED, $\geq 90 \%$ ), sodium perborate tetrahydrate $\left(\mathrm{NaBO}_{3} \cdot 4 \mathrm{H}_{2} \mathrm{O}, \geq 97 \%\right)$, nitric acid $\left(\mathrm{HNO}_{3}, \geq 69 \%\right.$, for trace analysis) were supplied by Fluka. Linear alkyl benzene sulfonate (LAS, MARLON AS 3) was acquired from Sasol Germany $\mathrm{GmbH}$. Silver standard solutions were prepared adding silver nitrate $\left(\mathrm{AgNO}_{3} \geq 99,8 \%\right)$ from SiGMA-Aldrich and were stored in the dark in order to prevent photo-reduction. Nitric acid $\left(\mathrm{HNO}_{3}, 65 \%\right)$ and Sodium Hydroxide $(\mathrm{NaOH} \geq 98 \%)$ used for $\mathrm{pH}$ adjustment were delivered by Fluka. Hydrogen peroxide $\left(\mathrm{H}_{2} \mathrm{O}_{2}, 30 \%\right)$ and peracetic acid solution $\left(\mathrm{C}_{2} \mathrm{H}_{4} \mathrm{O}_{3}, \geq 39 \%\right)$ were acquired from Fluka and titrated and standardized following the method described in [16]. Dilutions (in ca. $2 \% \mathrm{HNO}_{3}$ ) of silver plasma standard solution (Specpure Ag $1000 \mu \mathrm{g} / \mathrm{ml}, \mathrm{Ag}$ in $5 \% \mathrm{HNO}_{3}$ ) from Alfa Aesar were prepared for constructing the calibration for ICP-OES measurement. ECE detergent was used in the washing machine test (information in the Appendix B).

All solutions were prepared with nanopure water $(16-18 \mathrm{M} \Omega \mathrm{cm})$. The $\mathrm{pH}$ of the solutions and suspensions was measured by a pH-glass electrode (Metrohm) calibrated with buffer standard solutions at $\mathrm{pH} 4$ and 7 (Metrohm).

\subsection{Materials}

\section{Textiles}

Ten different Ag-textiles were included in this work but one commercial sample was found not to contain any $\mathrm{Ag}$ and was thus not further studied. Three of the fabrics used were commercially available anti-bacterial socks (AgkilbactTM, X-STATIC, AgACTIVE ${ }^{\mathrm{TM}}$ ), 6 were fabrics obtained directly from two companies and one was a sample from an ongoing research project at EMPA. 
Table 1- Fabrics used in the experiments and their silver content

\begin{tabular}{|c|c|c|c|c|}
\hline Textile label & Description textile & Ag-NP & $\begin{array}{c}\text { silver content }(\mathrm{mg} / \mathrm{g} \text { of } \\
\text { textile })\end{array}$ & RSD (\%) \\
\hline X-STATIC socks & $\begin{array}{c}79 \% \text { cotton, } 14 \% \\
\text { polyamide, } 6 \% \text { X-static } \\
\text { fiber, } 1 \% \text { Lycra } \otimes \text { Elasthane }\end{array}$ & $\begin{array}{l}\text { Layer of pure silver bound on } \\
\text { fibers (according to } \\
\text { manufacturer). }\end{array}$ & 21.6 & 7.34 \\
\hline PLASMA- NP & PES & $\begin{array}{l}\text { Plasma-coated fiber with Ag- } \\
\text { NP embedded in PES matrix }\end{array}$ & 0.39 & 4.17 \\
\hline AGCL & $100 \%$ cotton & $\begin{array}{l}\mathrm{AgCl}(\sim 200 \mathrm{~nm}) \text { bound to the } \\
\text { fiber surface (iSYS AG) }\end{array}$ & 0.008 & 9.93 \\
\hline AGCL binder & $100 \%$ cotton & $\begin{array}{l}\mathrm{AgCl}(\sim 200 \mathrm{~nm} \text { ) incorporated in } \\
\text { binder on the fiber (iSYS AG) }\end{array}$ & 0.012 & - \\
\hline NP-PES surface & PES & $\begin{array}{l}\text { Ag-NPs bound to the fiber } \\
\text { surface }\end{array}$ & 0.029 & - \\
\hline NP-PES & PES & $\begin{array}{c}\text { Ag-NPs incorporated into PES } \\
\text { fiber }\end{array}$ & 0.099 & - \\
\hline NP-PES/PA & PES + PA (80:20) & Ag-NPs incorporated into fiber & 0.242 & - \\
\hline X-SYSTEMS & $\begin{array}{c}50 \% \text { cotton, 39\% Polyester, } \\
6 \% \text { Nylon, 5\% Spandex }\end{array}$ & $\begin{array}{l}\text { Ag-NPs incorporated inside } \\
\text { one of the synthetic fibers } \\
\text { (polyester and/or nylon }\end{array}$ & 0.003 & 31.50 \\
\hline $\begin{array}{c}\text { Agkilbact }^{\mathrm{TM}} \\
\text { (SoleFresh }^{\mathrm{TM}} \text { ) socks }\end{array}$ & $\begin{array}{c}80 \% \text { cotton, } 20 \% \text { Elastic } \\
\text { Yarn }\end{array}$ & $\begin{array}{l}\text { Nano-size silver nanoparticles } \\
\text { incorporated into cotton fibres } \\
\text { (according to manufacturer). }\end{array}$ & 2.66 & 0,43 \\
\hline
\end{tabular}

Three replicates of an air-dry mass of each textile were digested with $3.5 \mathrm{ml}$ of $\mathrm{HNO}_{3}(65 \%)$ and $1 \mathrm{ml}$ of $\mathrm{H}_{2} \mathrm{O}_{2}$ (30\%). The digestion was carried out in a $\mathrm{GmbH}$ High Performance Microwave (MLS 1200 MEGA digestion system, EM-45/A Exhaust Module). Silver was quantified by inductively coupled plasma optical emission spectroscopy (ICP - OES Perkin Elmer OPTIMA 3000). NP-PES/PA was instead digested with $5 \mathrm{ml}$ of $\mathrm{HNO}_{3}(65 \%), 0.5 \mathrm{ml}$ of $\mathrm{H}_{2} \mathrm{O}_{2}(30 \%)$ and $0.5 \mathrm{ml}$ of hydrofluoric acid (HF). This latter analysis was performed by an external commercial laboratory commissioned by HeiQ Materials AG.

For NP-PES and NP-PES surface, the silver content in the samples was measured by X-ray Fluorescence Spectroscopy (at HeiQ quality testing laboratory). One commercial sample, AgACTIVE $^{\text {TM }}$ socks (75\% Cotton, 10\% Spandex, 15\% Elastic) did not contain any detectable Ag 
although the specifications of the manufacturer say that minute particles of silver (about one hundredth of a micron) were infused into the fabric.

\section{Nanoparticles}

Four types of Ag-particles were employed in the experiments. Type A (labelled NP-powder), type B (labelled Ag-powder (80-500 nm), Ag metal powder 99,95\%, 80-500 nm) and type C (labelled Ag-powder (1.5 -2.5 $\mu \mathrm{m}$ ), Ag metal powder 99,95\%, $1.5-2.5 \mu \mathrm{m}$ ) were obtained from Auer-Remy GmbH (Hamburg, Germany). In addition carbonate-coated Ag-NPs (labelled NPsuspension) were furnished by NanoSys $\mathrm{GmbH}$ (Wolfhalden, Switzerland) as an aqueous suspension ( $1 \mathrm{~g} \mathrm{~L}^{-1}, 9.27 \mathrm{mM}$, based on silver mass, $1 \%$ as $\mathrm{Ag}^{+}$) and kept in the dark.

The aggregate size of the silver nanoparticles was determined by an LM Nanosight instrument. In this instrument the particles or their aggregates in the liquid sample which pass through the beam path ( $80 \mu \mathrm{m}$ width) are seen as small points of scattered light moving under Brownian motion. The software Nanosight NTA 1.5.1 was used to track separately the trajectories of the single nanoparticle/cluster by the analysis of the particle dispersion video clips recorded.

Examples of the nanoparticle size distribution profiles for NP-powder and NP-suspension are shown in figure 1,2 and 3. Before the analysis, the Ag-NPs were ultrasonicated 5 minutes with an ultrasonication probe (BANDELIN Sonopuls Homogenisatoren HD 2070 - MS 7.3 mm - 70 W) at maximum power. The average Ag-NP size for the NP-powder was $104 \mathrm{~nm} \pm 9 \mathrm{~nm}$ and 83 $\mathrm{nm} \pm 7 \mathrm{~nm}$ at $\mathrm{pH} 7$ and 10 (in the presence of $0.1 \mathrm{~g} / \mathrm{L} \mathrm{SDS}$ ) respectively. For the NP-suspension at $\mathrm{pH} 10$ the mean diameter was $37 \mathrm{~nm} \pm 2 \mathrm{~nm}$.

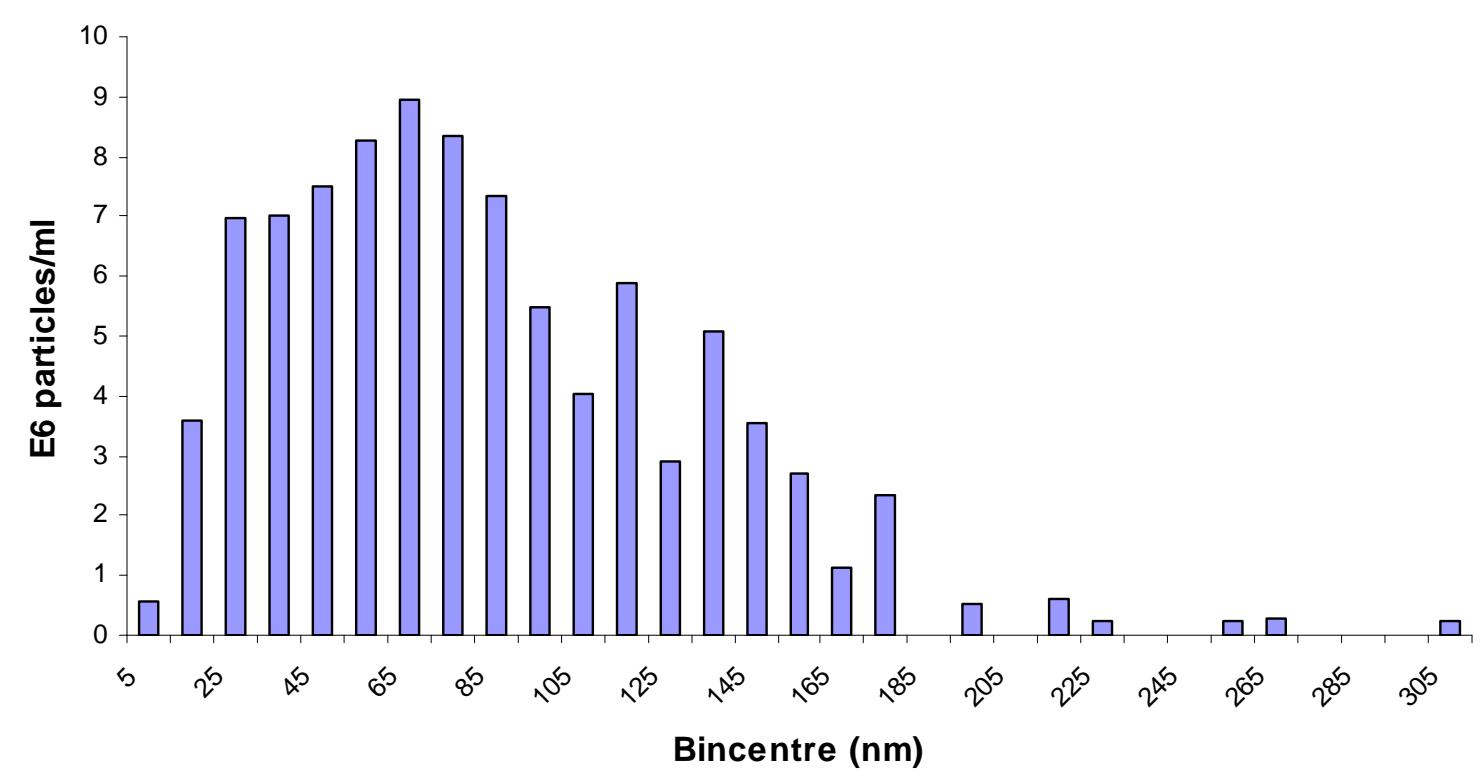


Figure 1- Size distribution profile of NP-powder in pH 10 suspension and in presence of SDS $(0.1 \mathrm{~g} / \mathrm{L})\left(25.2^{\circ} \mathrm{C}\right)$.

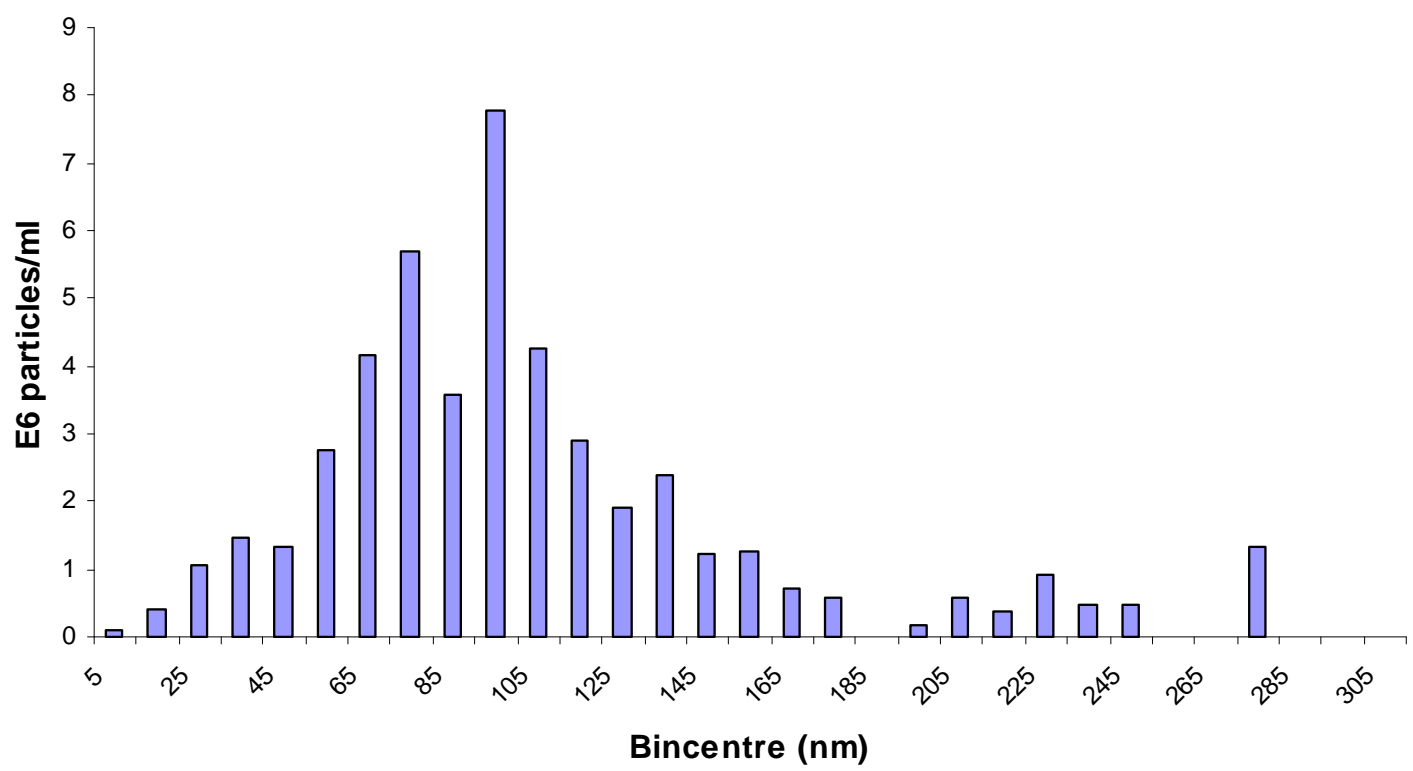

Figure 2- Size distribution profile of NP-powder in $\mathrm{pH} 7$ suspension and in presence of SDS $(0.1 \mathrm{~g} / \mathrm{L})\left(24.1^{\circ} \mathrm{C}\right)$

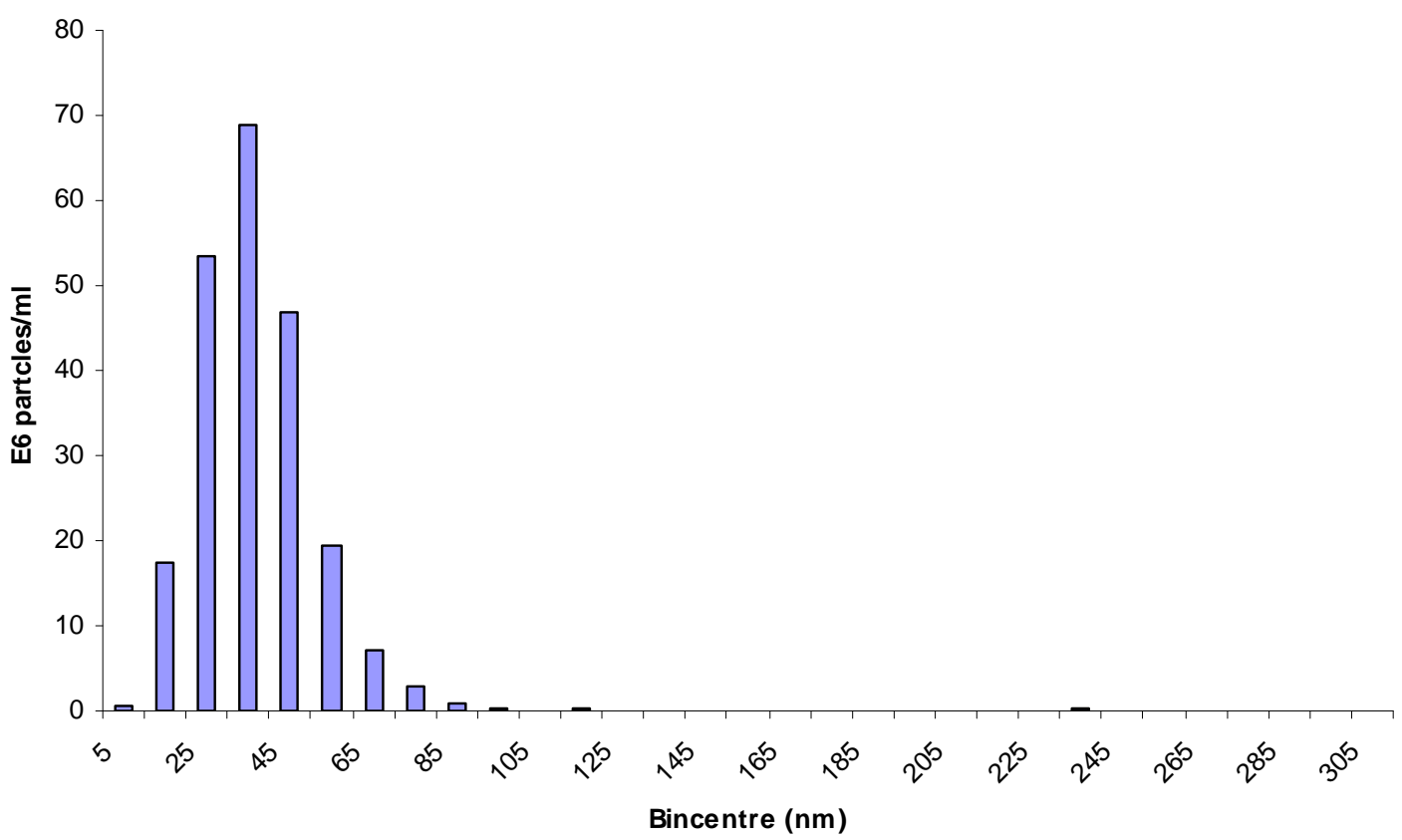

Figure 3-Size distribution profile of NP-suspension in $\mathrm{pH} 7$ suspension and in presence of SDS $(0.1 \mathrm{~g} / \mathrm{L})\left(21.3^{\circ} \mathrm{C}\right)$ 


\subsection{Silver ion $\left(\mathrm{Ag}^{+}\right)$measurement with lon-Selective Electrode (ISE)}

The free $\mathrm{Ag}^{+}$ion concentration was measured using an Ag-ISE (Metrohm 6.0502.180) coupled with a $\mathrm{Ag} / \mathrm{AgCl}$ reference electrode (Metrohm 6.0726.100) with double junction and potassium nitrate $\left(\mathrm{KNO}_{3}, 3 \mathrm{M}\right)$ as outer filling solution (bridge electrolyte). The potential was measured by a Metrohm pH-ISE voltmeter. Before each experiment a daily calibration curve was established from diluted $\mathrm{AgNO}_{3}$ standard solutions prepared in the $\mathrm{Ag}^{+}$range $1 \cdot 10^{-3}$ to $1 \cdot 10^{-6} \mathrm{M}$ and extended to $7.96 \cdot 10^{-8} \mathrm{M}$ by means of chloride addition $(\mathrm{NaCl})$ as ligand. Visual-MINTEQ program was utilized to calculate the resulting free $\mathrm{Ag}^{+}$concentration upon the addition of $\mathrm{NaCl}$. The same program was used for computing the total dissolved silver concentration in solution (shown in the figures of this paper). The free ionic silver was around $1.5 \%$ and $1.8 \%$ less than total dissolved silver concentration at $\mathrm{pH} 7.1$ and $\mathrm{pH} 10$ respectively. $0.03 \mathrm{M}$ Sodium nitrate $\left(\mathrm{NaNO}_{3}\right)$ was used to set the ionic strength and sodium carbonate $\left(\mathrm{Na}_{2} \mathrm{CO}_{3}, 0.005 \mathrm{M}\right)$ or MOPS $(0.01 \mathrm{M})$ was added to the solution as buffer. The interference of the different components used in the experiments (e.g. buffers, ionic medium, detergents and $\mathrm{pH}$ ) on the ISE signal was initially tested. Silver nitrate $\left(\mathrm{AgNO}_{3}\right)$ solutions $\left(10^{-5} \mathrm{M}\right.$ and $\left.10^{-3} \mathrm{M}\right)$ were prepared for this purpose. In no case the measured potential changed by more than $2 \%$. For hydrogen peroxide concentrations up to $2 \mathrm{mM}$ no noise was observed. The ISE did not show a stable signal in the ESE detergent and $\mathrm{Ag}^{+}$analysis was not possible.

\subsection{Dissolution of silver nanoparticles (Ag-NP)}

All measurements were carried out at room temperature in glass vessels protected from light in order to avoid photo-reduction of silver. The suspensions were always subjected to mild (100$150 \mathrm{rpm}$ ) stirring condition. Absorption of $\mathrm{Ag}$ on the glass walls was tested preparing a $\mathrm{AgNO}_{3}$ standard solution of $9.28 \cdot 10^{-7} \mathrm{M}$ and checking the change of the $\mathrm{mV}$ signal over time. After 50 minutes a decrease of $<1 \mathrm{mV}\left(<5.55 \cdot 10^{-8} \mathrm{M} ;<5.9 \%\right)$ was observed.

In all the experiments $\mathrm{NaNO}_{3}$ was used to set the ionic strength (0.03) and $\mathrm{Na}_{2} \mathrm{CO}_{3}(\mathrm{pH} 10)$ or MOPS ( $\mathrm{pH}$ 7.1) buffers were added to stabilize the $\mathrm{pH}$. The Ag-NPs were always added to the solution as powder (except the NP-suspension which were injected as suspension) and the dispersion was ultrasonicated with an ultrasonication probe (BANDELIN Sonopuls Homogenisatoren HD 2070 - MS 7, 3 mm - 70 W) for 5 minutes at maximum power.

The dissolution of the Ag-NPs was followed over time recording periodically the potential measured by the ISE/pH voltmeter. The $\mathrm{pH}$ was also checked at the beginning and the end of the experiments. SDS $(0.1 \mathrm{~g} / \mathrm{l})$ and LAS (ca. $0.1 \mathrm{~g} / \mathrm{l})$ surfactants as well as oxidizing agents $\left(\mathrm{H}_{2} \mathrm{O}_{2}\right.$, PAA) were added to the solution in order to investigate their influence upon Ag-NP dissolution. The bleaching agent perborate and the bleach activator TAED were also applied to the system. 


\subsection{Hydrogen peroxide effect on $\mathrm{Ag}^{+}$}

The effect of hydrogen peroxide on $\mathrm{Ag}^{+}$was investigated at $\mathrm{pH} 10$ (carbonate buffered) adding $0.002-0.04 \mathrm{mmol}$ of $\mathrm{H}_{2} \mathrm{O}_{2}$ to $50 \mathrm{ml}$ of silver standard solutions $\left(\mathrm{AgNO}_{3}\right)$ in the $0.1 \mathrm{mM}-1 \mu \mathrm{M}$ concentration range. The potential was reported at regular intervals. SDS $(0.1 \mathrm{~g} / \mathrm{L})$ was included in the system.

\subsection{Release of silver ( $\mathrm{Ag})$ from textiles: influence of oxidizing agents and $\mathrm{pH}$}

The release of silver from the textiles was studied under controlled conditions at $\mathrm{pH} 10$ with SDS as surfactant $(0.1 \mathrm{~g} / \mathrm{l})$. The samples were subjected to gentle agitation (stirring rate 100-150 $\mathrm{rpm})$ and protected from light. The amount of fabric placed into solution $(50 \mathrm{ml})$ ranged from 4.9 to $36.2 \mathrm{~g}$ textile/L. This large interval was due to the fact that some specimens had very low silver content and consistently more material was needed in order to detect silver in solution. The total silver introduced into the system varied from $1 \cdot 10^{-6}$ to $1 \cdot 10^{-3} \mathrm{M}$. Similarly to the Ag-NP dissolution experiments the ISE signal was recorded over time. In addition aliquots of the solution were taken for ICP-OES measurement with (PP+PE) plastic syringe at different times. The silver in the solution was size-separated using cellulose nitrate membrane filter $(0.45 \mu \mathrm{m}$ pore diameter, Sartorius Stedim Biotech Gmbh).

For two sock brands, free $\mathrm{Ag}^{+}$-evolution was also investigated for 1 hour in $\mathrm{pH} 7$ solution after transfer from $\mathrm{pH} 10$ solution. In this case $\mathrm{H}_{2} \mathrm{O}_{2}$ was used instead of PAA. This procedure was repeated for three consecutive days using the same textile piece.

\subsection{Wash of textile samples in the washing machine}

The washing procedure was conducted following the method provided in the norm ISO 105C06:1997. For this experiment a Washtec-P Roaches washing machine was used (motor speed $40 \pm 2 \mathrm{rpm}$, steel vessels (75 $\pm 5 \mathrm{~mm}$ diameter, $125 \pm 10 \mathrm{~mm}$ height, capacity of $550 \pm 50 \mathrm{ml}$ )) Since the steel containers leached significant amounts of $\mathrm{Ag}$, a modification of the system was needed. Polyethylene - HD - bottles were therefore embedded in the steel beakers and completely surrounded by water for assuring heat transfer.

The detergent/container volume ratio $(0.279)$ was kept the same as in the steel vessel (overall $81 \mathrm{ml}$ of ECE-detergent were used). The detergent was prepared dispersing ECE powder in distilled water (4 $\mathrm{g}$ ECE per litre). The textile samples were placed inside the HD-bottles and cut when required to fit in there. The quantity of material utilized ranged from 4.7 to $27.4 \mathrm{~g}$ textile/L. The total silver introduced into the system varied from $1.9 \cdot 10^{-6}$ to $1 \cdot 10^{-3} \mathrm{M}$. In a cycle the 
samples were washed for 30 minutes at $40^{\circ} \mathrm{C}$ and sub jected to mechanical stress by 10 steel balls previously cleaned in $\mathrm{HNO}_{3}(65 \%)$.

After the specified contact time the fabrics were removed and rinsed with nanopure water for 12 seconds before wiping with soft tissues and letting them dry for the next washing. From the detergent liquor a $15 \mathrm{ml}$ aliquot was filtered with a cellulose nitrate membrane $(0.45 \mu \mathrm{m}-$ Whatman) and part of it further centrifuged (10 minutes, $F=5000 \mathrm{~g}$ ) through Amicon Ultra centrifugal filter (MW cut-off $30 \mathrm{kDa}$-purchased from Millipore). The rest in the HD-bottle was mixed by an ultrasonic probe for 2 minutes and three replicates of $10 \mathrm{ml}$ were taken and evaporated at $85{ }^{\circ} \mathrm{C}$ in the oven overnight. Following up the addition of $1 \mathrm{ml} \mathrm{HNO}_{3}$ (69\%) and the heating at $85{ }^{\circ} \mathrm{C}$ for $15-30 \mathrm{~min}$, these samples (total $\mathrm{Ag}$ release analysis) were filtered (cellulose nitrate membrane $0.45 \mu \mathrm{m}$; Sartorius Stedim Biotech $\mathrm{Gmbh}$ ) and diluted for ICP-OES measurements. Few microlitres of $\mathrm{HNO}_{3}(69 \%)$ were added when necessary for storage and to lower the $\mathrm{pH}$ in the ICP-OES calibration range.

In appendix $\mathrm{E}-\mathrm{H}$ the number of cycles performed are summarized. In one cycle perborate powder $(1 \mathrm{~g} / \mathrm{l})$ and TAED solution $(0.15 \mathrm{~g} / \mathrm{l})$ were added to the detergent immediately before the washing machine treatment. These compounds acted as bleaching agent and bleach activator respectively. In both the beaker and washing machine experiment the initial concentration of $\mathrm{Ag}$ in solution was maintained on a comparable range.

Before the wash with the textile samples a set of preliminary tests were performed to asses the possible losses or contaminations of silver during the experiment. First of all the washing machine was run in the same condition as in the textile trial with only the detergent or the detergent plus the cleaned steel balls in the HD bottles. Then two aliquots of $10 \mathrm{ml}$ were taken before and after ultrasonication (for 2 minutes) and filtered with cellulose nitrate membrane (size-pore $0.45 \mu \mathrm{m}$ ). In both cases the ICP- OES silver signal was under detection limit.

To account for the possible absorption on the steel balls or on HD-bottle walls, a similar test was executed spiking a known amount of silver solution into the detergent water and measuring the concentration before and after a cycle. Around $15 \%$ of Ag was lost at the end. In order to reckon the loss in filtering the samples a $\mathrm{AgNO}_{3}$ standard solution was prepared and filtered through cellulose nitrate and AMICON membrane. An overall absorption of around $2-8 \%$ and $12-16 \%$ was evaluated, respectively. 


\section{3- Results}

\subsection{Ag-NP dissolution}

The dissolution of two types of Ag-NP (NP-powder and NP-suspension) in the presence or absence of surfactants (SDS and LAS) was investigated (Figure 4). The evolution of the silver concentration was followed for $\sim 3$ hours. The experiment can be divided in two phases i) in the first phase the Ag-NPs were dispersed into the $\mathrm{pH} 7$ solution and the ISE potential was recorded for two hours at intervals (except curve 1), ii) in the second phase the oxidant $\left(\mathrm{H}_{2} \mathrm{O}_{2}\right.$ ) was added to the system (arrows) and the change of $\mathrm{Ag}$ concentration detected for $\sim 1$ hour. No relevant differences were found in the oxidation of the carbonate-coated Ag-NPs (NPsuspension) with or without SDS surfactant in the suspension (curve 3 and 4). The dissolution rate of the Ag-NPs after the addition of $\mathrm{H}_{2} \mathrm{O}_{2}$ was very similar for the NP-powder and the NPsuspension, independently of the surfactant (curves 2, 3, 4 and 5): the $\mathrm{Ag}^{+}$concentrations measured after 180 minutes increased by a factor of $\sim 80$ (up to $8.83 \cdot 10^{-5} \mathrm{M}$ ) (curve 2-from 0.12 to $9.72 \%$ of total silver), $\sim 61$ (up to $8.47 \cdot 10^{-5} \mathrm{M}$ ) (curve 3-from 0.74 to $45.54 \%$ of total silver), $\sim 59$ (up to $9.28 \cdot 10^{-5} \mathrm{M}$ ) (curve 4 -from 0.84 to $49.92 \%$ of total silver) and $\sim 76$ (up to $1.53 \cdot 10^{-4}$ M) (from 1.13 to $83 \%$ of total silver - curve 5 ) after the addition of the oxidant. 


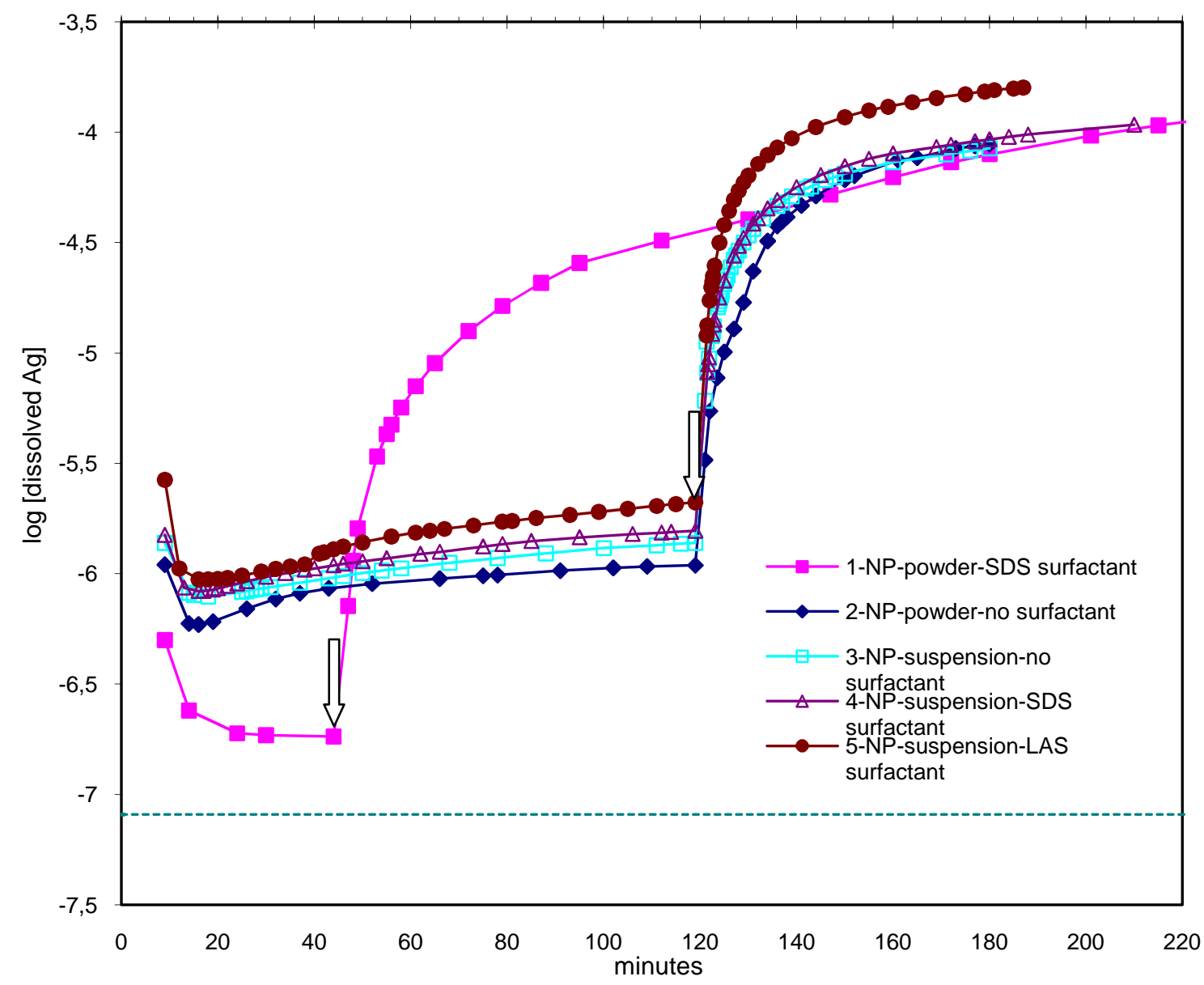

Figure 4-Dissolution of Ag-NPs at pH 7.1: the arrows indicate the time-point of $\mathrm{H}_{2} \mathrm{O}_{2}(0.088 \mathrm{mM}$ in solution) addition. The initial concentration of $\mathrm{Ag}$ in the experiments was $1.86 \cdot 10^{-4}$ (curve 3, 4 and 5 ) for the carbonatecoated Ag-NPs (NP-suspension) and varied from $9.09 \cdot 10^{-4}$ (curve 2) to $9.47 \cdot 10^{-4}$ (curve 1) for the NP-powder. The same amount of $\mathrm{H}_{2} \mathrm{O}_{2}$ was always added in each experiment $(0.088 \mathrm{mM}$ in solution). The dashed line indicates the lowest limit of ISE calibration range (detection limit)

Figure 5 summarizes the experiments about the dissolution of Ag-NPs (NP-powder and NPsuspension), carried out at $\mathrm{pH} 10$ with the addition of different oxidizing compounds. The graph can be again analyzed separating the curves in three parts: i) release of dissolved silver from Ag-NP in the absence of oxidant (first 120-129 minutes), ii) oxidation of the Ag-NPs after the first addition of oxidant, iii) further oxidation of the Ag-NPs after the second injection of the oxidant. For all the tests conducted, the $\mathrm{Ag}^{+}$signal in the first part (i) resulted to be close or under the detection limit. Comparing the behavior of NP-powder in figure 4 (curve 2 - first 120 minutes) and figure 5 (curve $\mathrm{B}$ - first 120 minutes), the $\mathrm{Ag}^{+}$concentration was lower by around a factor of 10 at $\mathrm{pH} 10$ compared to $\mathrm{pH}$ 7. Analyzing the second stage of the experiment (ii), it can be noticed that the NP-suspension was oxidized less by $\mathrm{H}_{2} \mathrm{O}_{2}$ than the NP-powder (curve $\mathrm{C}$ and D). Peracetic acid (1mM) dissolved the Ag-NP (NP-powder) more than 100 times more (curve 
A) compared to hydrogen peroxide (curve $C$ ). The compounds TAED and perborate were also added in the Ag-suspensions at $40{ }^{\circ} \mathrm{C}$ : their initia I concentrations in the solution were the same as in the washing machine test. According to figure 5 (curve $F$ and $G$ ) the combination of these two compounds augmented the oxidation of the Ag-NPs (NP-powder) by almost a factor of 1000. In both curves $F$ and $G$ the ISE signal steadily decreased after the surge following the addition of the oxidants.

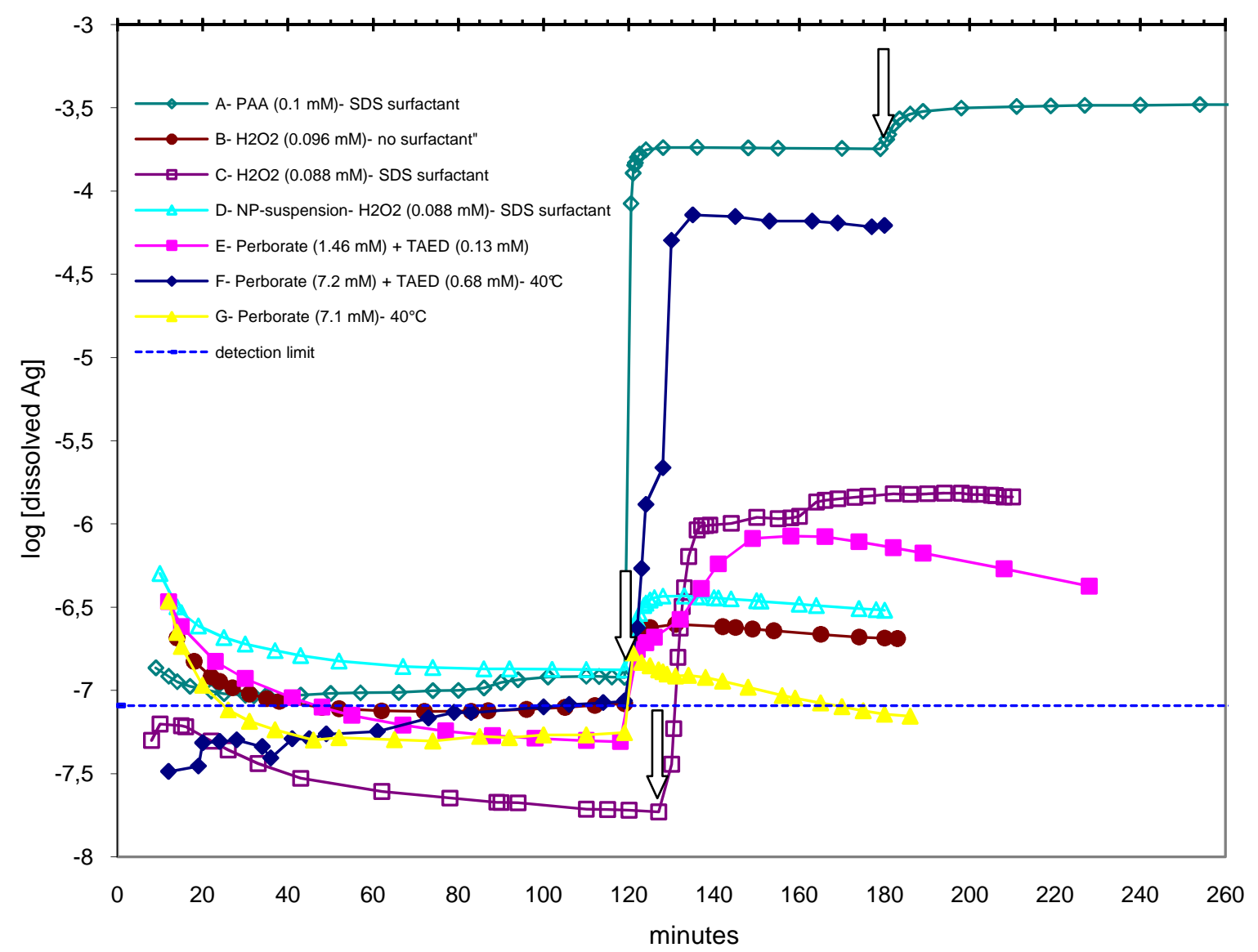

Figure 5- Dissolution of Ag-NPs at pH 10: the arrows indicate the time-point of oxidant addition. The initial concentration of the carbonate-coated NPs (NP-suspension) was $1.86 \cdot 10^{-4} \mathrm{M}$ and varied from $9.72 \cdot 10^{-4}$ to 9.25.10 ${ }^{-4} \mathrm{M}$ for the NP-powder. Unless otherwise indicated, all the curves refer to NP-powder. The dashed line stands for the lowest limit of the ISE calibration range (detection limit)

Comparing figure 4 and 5, the dissolution rate for both the NP-powder and NP-suspension was higher at $\mathrm{pH} 7.1$ (curve 1 and 4) than at $\mathrm{pH} 10$ (curve $\mathrm{C}$ and $\mathrm{D}$ ). The same behavior was found in absence of the SDS (curve 2 and 3-fig- 4 and curve $C$ and D-fig 5). 


\section{Dependence of Ag-NP size on Ag-NP dissolution}

The role of the silver NP-size on the dissolution was assessed in presence of $0.088 \mathrm{mM} \mathrm{H}_{2} \mathrm{O}_{2}$ as oxidant (figure 6) and SDS as surfactant $(0.1 \mathrm{~g} / \mathrm{L})$. Three Ag-NPs of different size-range were used in the experiments: NP-powder (83 nm \pm 7 ), Ag-powder $(80-500 \mathrm{~nm}), \mathrm{Ag}$-powder (1.5- 2.5 $\mu \mathrm{m})$. In the first part of the test the Ag-NPs were added to the solution without $\mathrm{H}_{2} \mathrm{O}_{2}$. Plainly the specific surface area of the NPs governed the $\mathrm{Ag}^{+}$release in $\mathrm{pH} 7$ solution. The nanoparticles oxidation by $\mathrm{H}_{2} \mathrm{O}_{2}$ was more effective for NP-powder than for Ag-powder (80-500 nm) and Agpowder (1.5- $2.5 \mu \mathrm{m}$ ): the Ag concentration increased by a factor of $\sim 832$ (after 240 minutes), 32 and 2 respectively (after 60 minutes). The release of $\mathrm{Ag}^{+}$from the $\mathrm{Ag}-\mathrm{NPs}$ did not take place for the biggest Ag-NPs (Ag-powder (1.5- $2.5 \mu \mathrm{m})$ ) after 2 hours of contact with water: the ISE signal constantly went down reaching the detection limit point. On the contrary a steady increase of the $\mathrm{Ag}^{+}$concentration up to $2.35 \cdot 10^{-7} \mathrm{M}$ was observed for Ag-powder (80-500 nm) after 2 hours of immersion.

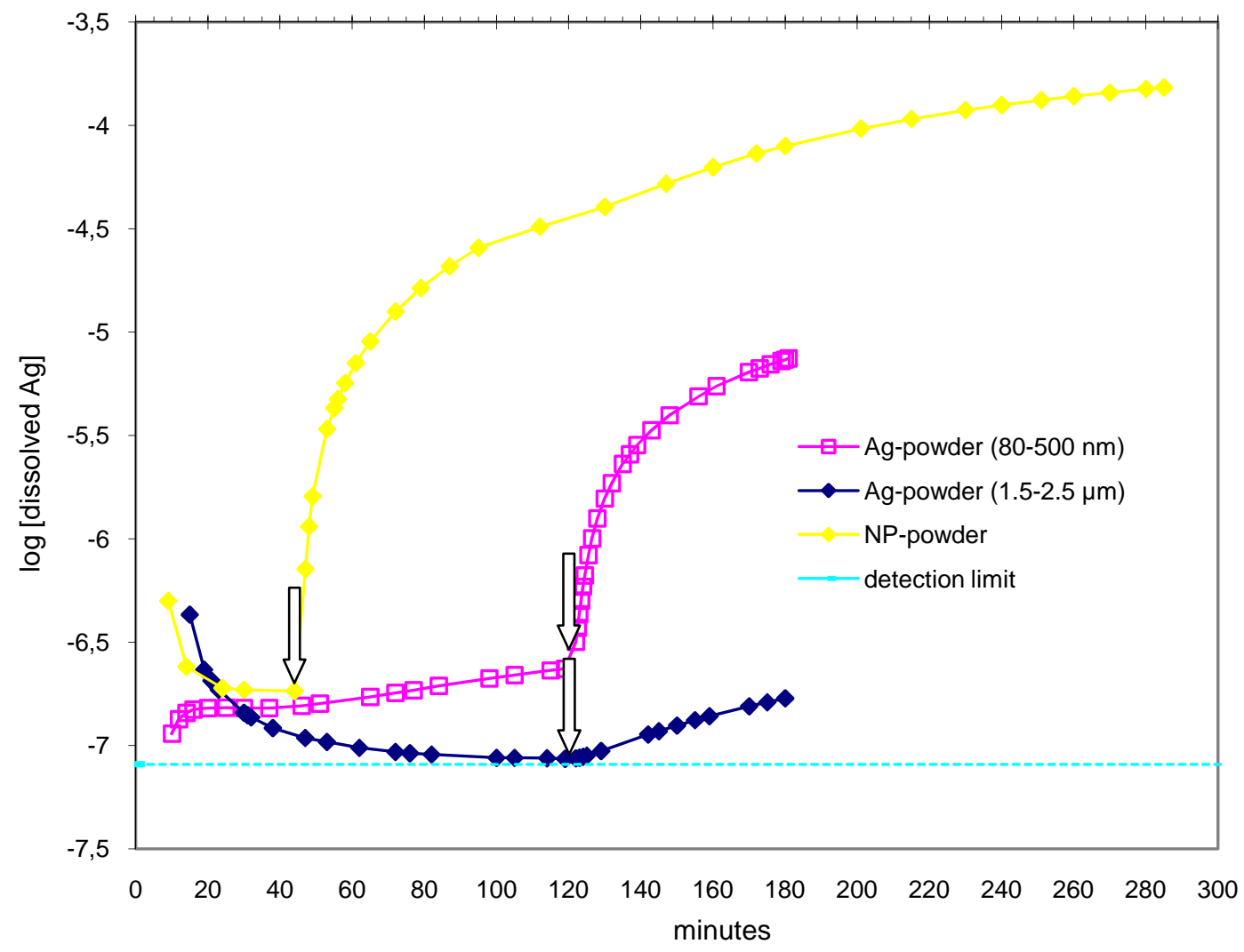

Figure 6- Dissolution of Ag-NPs at pH 7 in the presence of SDS $(0.1 \mathrm{~g} / \mathrm{L})$. The arrows indicate the time-point of $\mathrm{H}_{2} \mathrm{O}_{2}\left(0.088 \mathrm{mM}\right.$ in solution) addition. The initial Ag-NPs concentration varied from $9.47 \cdot 10^{-4}$ to $1.10 \cdot 10^{-3} \mathrm{M}$ The dashed line stands for the lowest limit of the ISE calibration range (detection limit) 


\subsection{Hydrogen peroxide effect on $\mathrm{Ag}^{+}$}

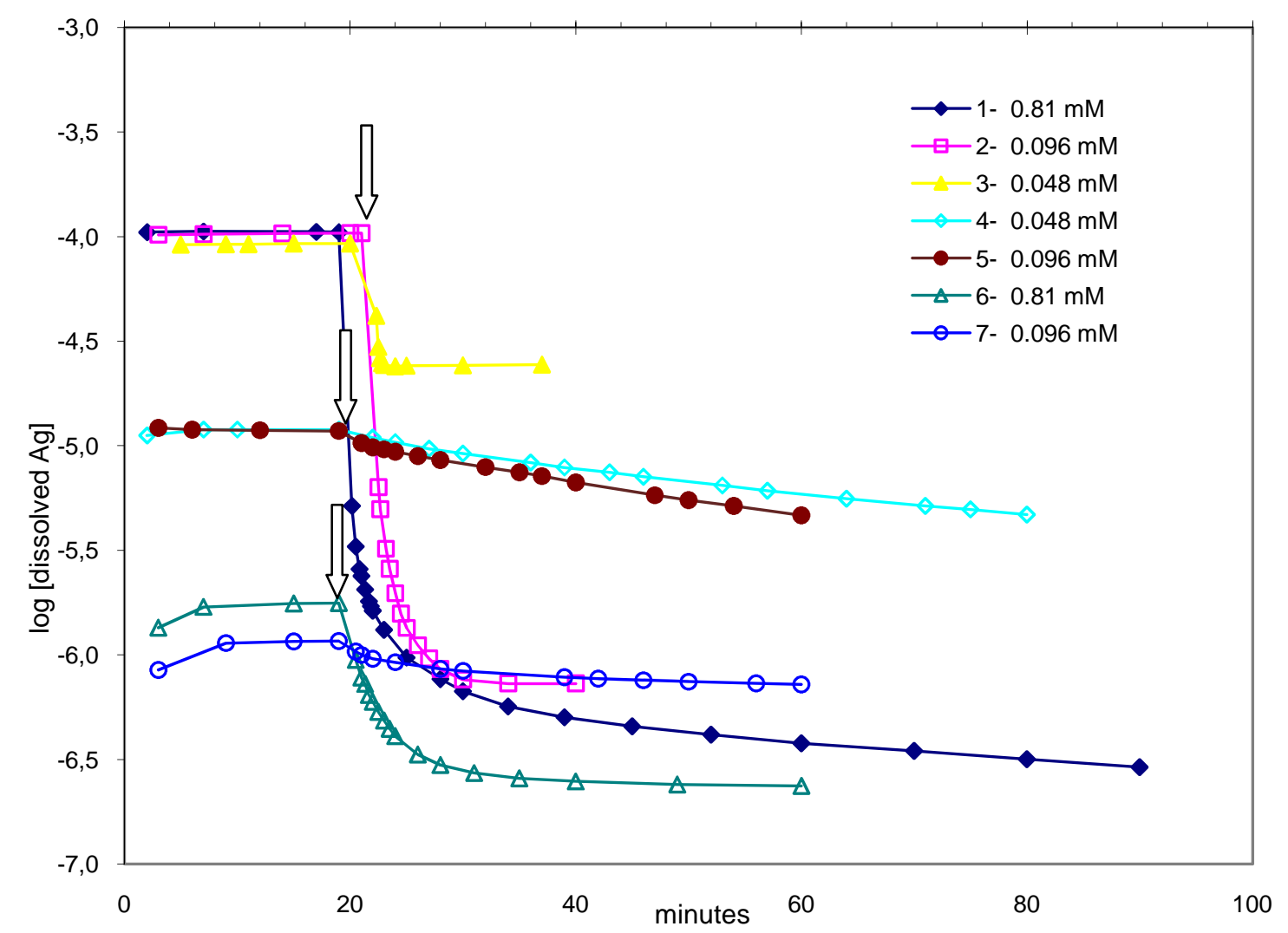

Figure 7- Effect of $\mathrm{H}_{2} \mathrm{O}_{2}$ on $\mathrm{Ag}^{+}$at $\mathrm{pH}$ 10-the arrows indicate the time-point of $\mathrm{H}_{2} \mathrm{O}_{2}$ addition (mM in solution)

The effect of hydrogen peroxide on $\mathrm{Ag}^{+}$was examined at $\mathrm{pH} 10$ by adding $0.002-0.04 \mathrm{mmol}$ of $\mathrm{H}_{2} \mathrm{O}_{2}$ to $50 \mathrm{ml}$ of silver standard solutions $\left(\mathrm{AgNO}_{3}\right)$ in the $0.1 \mathrm{mM}-1 \mu \mathrm{M}$ concentration range. In all the tests performed, the concentration of silver ions decreased after the addition of $\mathrm{H}_{2} \mathrm{O}_{2}$ (Figure 7). A formation of a yellow-milky precipitate was clearly noticed in the $\mathrm{AgNO}_{3}$ solutions $\left(1 \cdot 10^{-4} \mathrm{M}\right)$. Analyzing the curve 2 and 7 , an overlap can be seen and a decrement of the $\mathrm{Ag}^{+}$ signal to circa the same points after 40 minutes, that is $7.98 \cdot 10^{-7} \mathrm{M}$ (curve 7) and $7.44 \cdot 10^{-7} \mathrm{M}$ (curve 2) respectively. In the same way the addition of $\mathrm{H}_{2} \mathrm{O}_{2}(0.81 \mathrm{mM})$ into $\mathrm{AgNO}_{3}$ standard solution $\left(1 \cdot 10^{-4} \mathrm{M}\right)$ provoked a rapid drop in the $\mathrm{Ag}^{+}$concentration down to $2.96 \cdot 10^{-7} \mathrm{M}$ after 90 minutes (curve 1). This value approached the final concentration of $\mathrm{Ag}\left(2.41 \cdot 10^{-7} \mathrm{M}\right)$, reached after 60 minutes, in the trial with an initial $\mathrm{AgNO}_{3}$ concentration of $1.80 \cdot 10^{-6} \mathrm{M}$ (curve 6). A different behavior was found in the $\mathrm{AgNO}_{3}$ standard solution with an initial concentration of $1.2 \cdot 10^{-5} \mathrm{M}$. In this case the addition of $\mathrm{H}_{2} \mathrm{O}_{2}(0.096 \mathrm{mM})$ caused a decrease of the $\mathrm{Ag}^{+}$signal (curve 5) which is around 10 times lower than in curve 2. 


\subsection{Silver released from textile samples in SDS/pH 10 solution}

The textile specimens were immersed in $\mathrm{pH} 10$ solution in the presence of SDS as surfactant $(0.1 \mathrm{~g} / \mathrm{L})$. The evolution of the dissolved Ag was recorded over time (figure 8). The experiment can be subdivided into three parts: i) release of Ag into solution in the absence of PAA (first 120 minutes); ii) addition of the first aliquot of PAA ( $0.1 \mathrm{mM}$ in solution) and iii) $2^{\text {nd }}$ addition of PAA ( $0.5 \mathrm{mM}$ in solution). On a relative basis, Agkilbact ${ }^{\mathrm{TM}}$ sample exhibited the fastest and the biggest Ag release into solution for the first 30 minutes. Around $25 \%$ of its silver content was released very rapidly and this percentage stayed more or less the same until the second PAA addition. A pronounced increase of the dissolved Ag fraction was found for the PLASMA-NP specimen after the first and the second PAA addition.

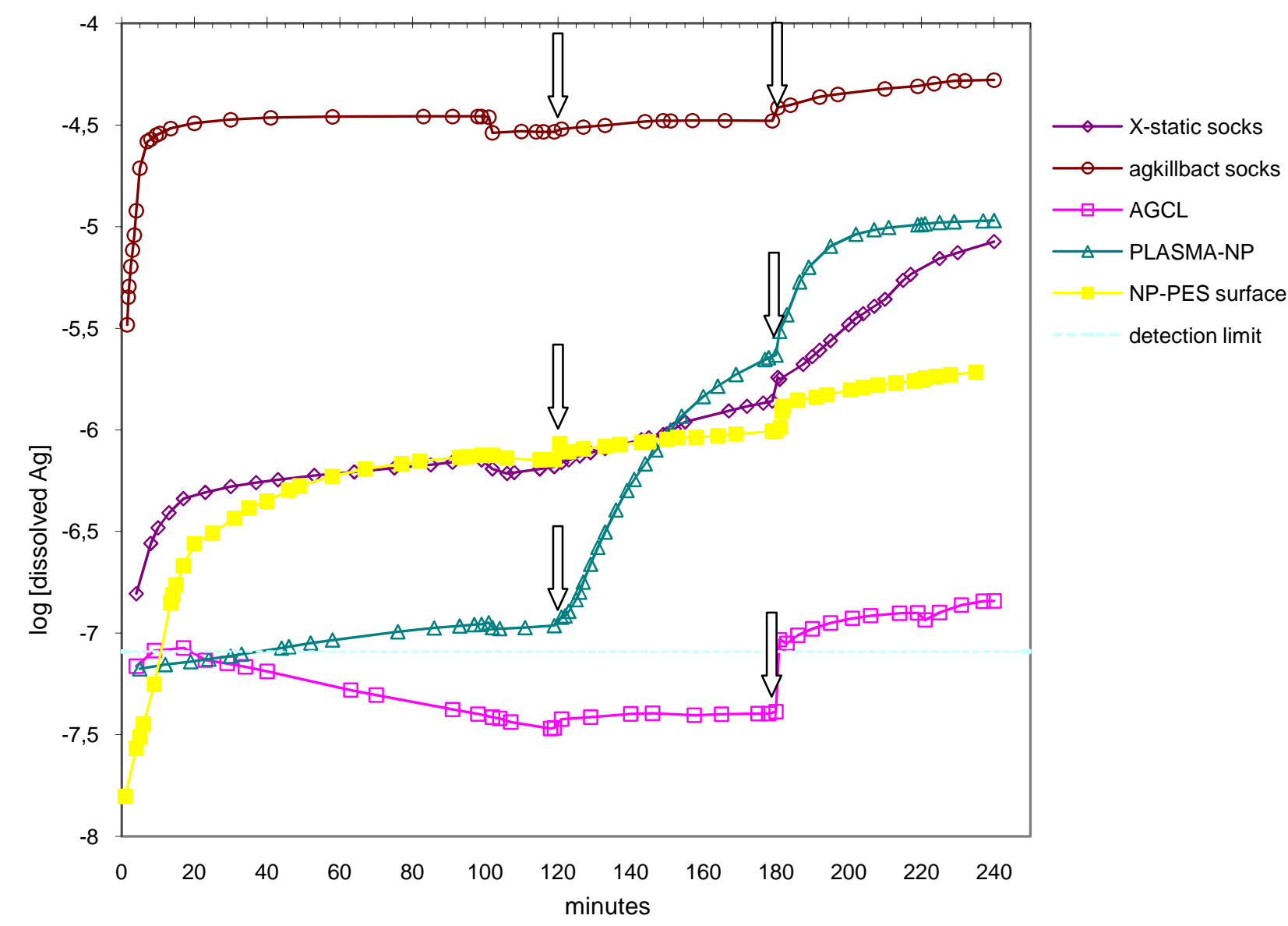

Figure 8- Ag release from textiles at $\mathrm{pH} 10$ in the presence of SDS $(0.1 \mathrm{~g} / \mathrm{L})$, with two additions of PAA (0.1 mM and $0.5 \mathrm{mM}$ in solution) after 120 and 180 minutes. For all the other samples, not shown in the figure, the silver concentration was found below the lowest limit of ISE calibration range. The table with initial Ag concentrations of the samples is attached in the appendix C or D. The dashed line stands for the lowest limit of ISE calibration range (detection limit) 
X-static and NP-PES SURFACE displayed a constant release of dissolved silver into solution over time. After the $2^{\text {nd }}$ addition of PAA, the X-static rate of silver release boosted. Nonetheless, only $0.8 \%$ of the silver textile content was leached at the end of the experiment for this sample. On the contrary, $83 \%$ of the silver contained in NP-PES SURFACE was found in solution at the end of the experiment. For all the other samples, not shown in figure 8 , the silver concentration was found below the ISE calibration range.

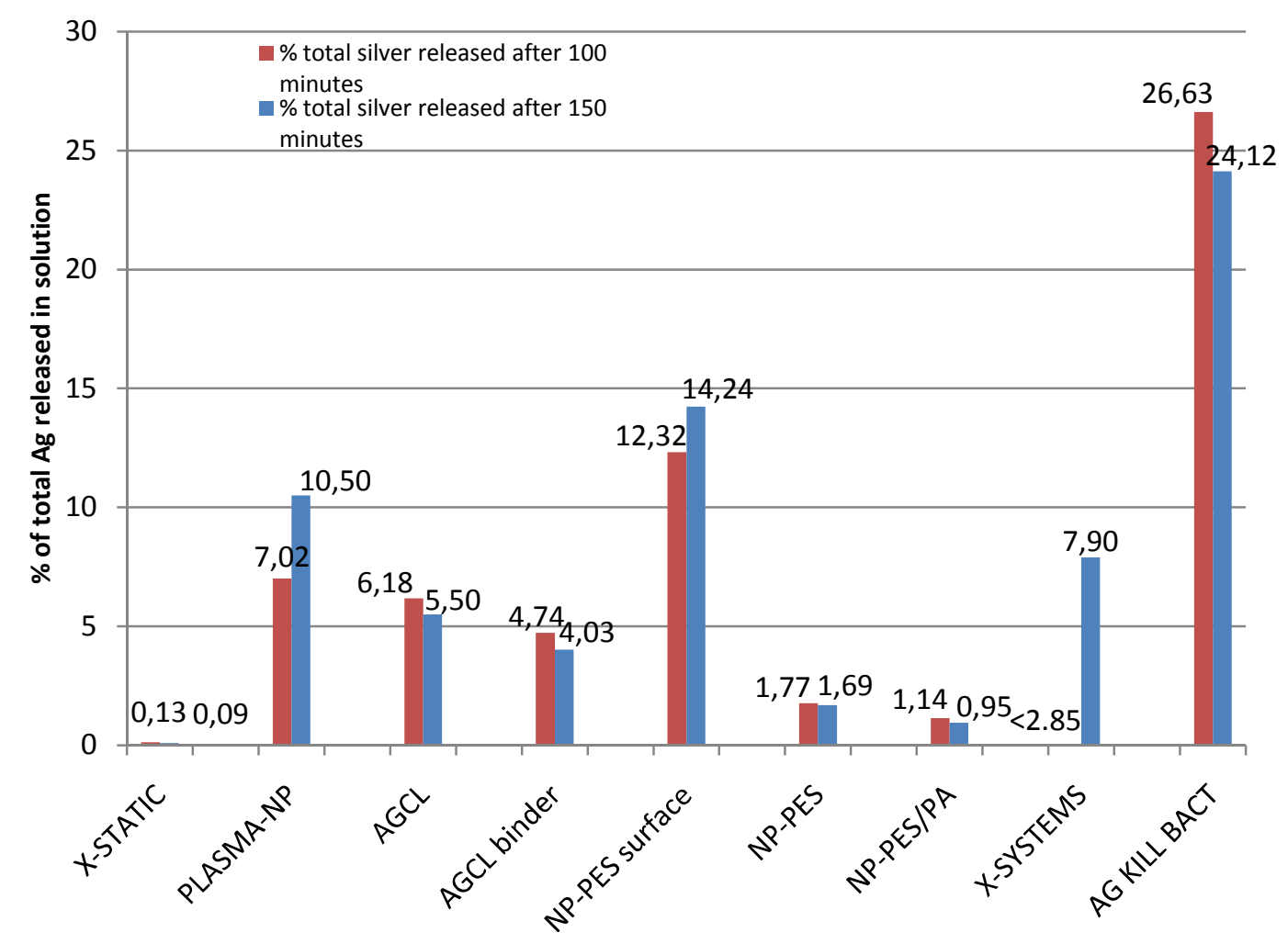

Figure 9- \% total silver released. The table with initial Ag concentrations of the samples is attached in the appendix $\mathbf{C}$ or D

Looking at figure 9, most of the samples leached in solution $0-11 \%$ of their total Ag content, except Agkilbact ${ }^{\mathrm{TM}}$ and NP-PES SURFACE which discharged $~ 26 \%$ and $14 \%$ respectively. After 100 minutes, no $\mathrm{Ag}(<2.85 \%$ of the textile $\mathrm{Ag}$ content) was detected in solution for $\mathrm{X}$ SYSTEMS. On the contrary this sample showed a release of circa $8 \%$ after 150 minutes of immersion. For X-static, a very small percentage $(\sim 0.1)$ of its total $\mathrm{Ag}$ was found in the medium during all the experiment. 
From the analysis of figure 10 and 11, the ionic silver resulted to be the prevalent form in solution for the samples X-static (only after the PAA addition), Agkilbact ${ }^{\mathrm{TM}}$ and NP-PES surface. For AGCL, AGCL BINDER, NP-PES/PA, NP-PES and X-SYSTEMS, the silver in the coarsegrained fraction accounted for $\sim 40-100 \%$ of the total silver released. The $2^{\text {nd }}$ addition of PAA provoked the disappearance of half of this fraction for X-static.

Several of the fractions shown in figure 10 and 11 gave total Ag results below the detection limit of the ISE or ICP-OES measurement. The concentration at the detection limit was converted for each fabric into the maximum silver fraction that could have been leached. This is especially important for the fabrics with very low $\mathrm{Ag}$ content. It is thus essential to realize that the fraction named "particles $<450 \mathrm{~nm}$ "in figure 10, 11, 14, 15, 16 includes Ag-NPs and small fiber particles containing silver or Ag-NPs. Moreover in figure 10 and 11, for the samples AGCL, AGCL BINDER and NP-PES/PA, this fraction could represent Ag-NP, dissolved Ag, small silver containing fibers or all these forms. The ISE did not measure a $\mathrm{Ag}^{+}$release less than $0.7-4.3 \%$ of the total Ag-content in these textiles which could account for all the filtered fraction (particles $<450 \mathrm{~nm}$ ) in figure 10 and 11. In fact the total Ag leached in solution and the filtered samples (passing $0.45 \mu \mathrm{m}$ size pore) were quantified with ICP-OES, which has a lower detection limit. Nonetheless it can not be measured circa $34 \%$ and $36 \%$ of the total $\mathrm{Ag}$ released from the sample NP-PES in figure 10 and 11 respectively. The silver in these fractions could be in whatever form. The same reasoning has to be done for X-SYSTEMS where the percentage results to be $36 \%$ in figure 11 and $100 \%$ in figure 10 .

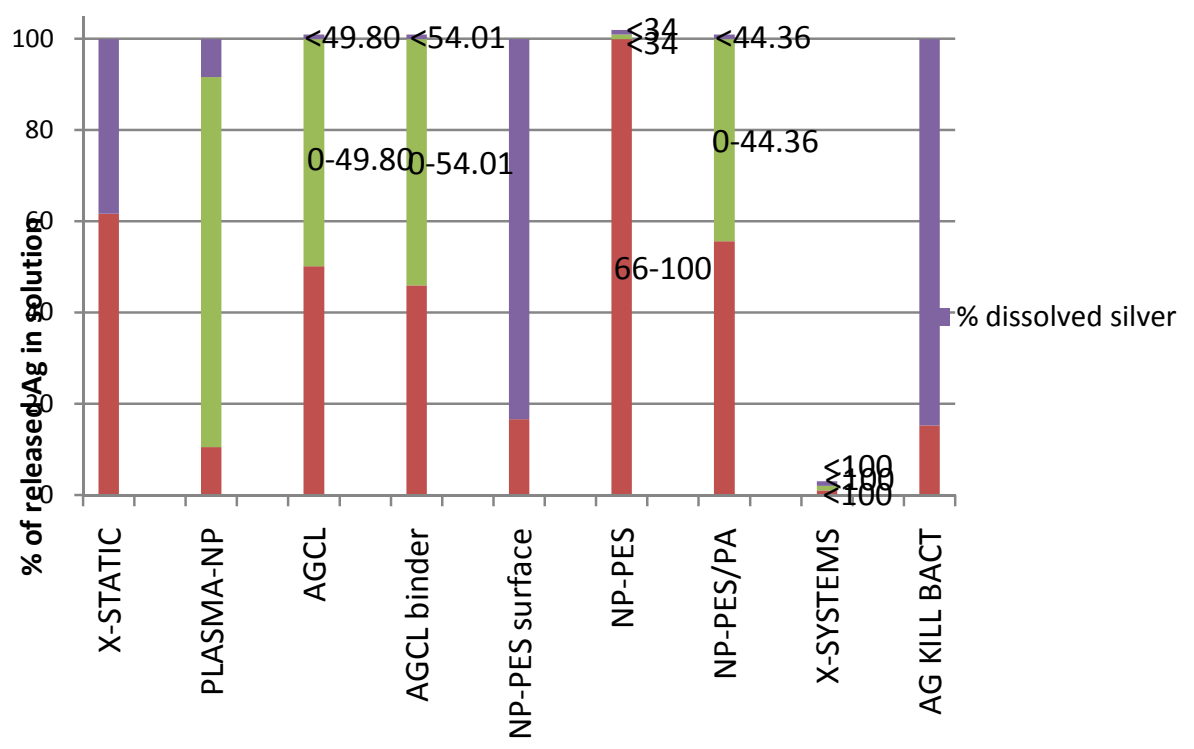

Figure 10 -Fractions of total Ag released after 100 minutes of textile immersion. The expression "< percentage number" represents the \% released based on the detection limit of the methods (ISE or ICP-OES). 


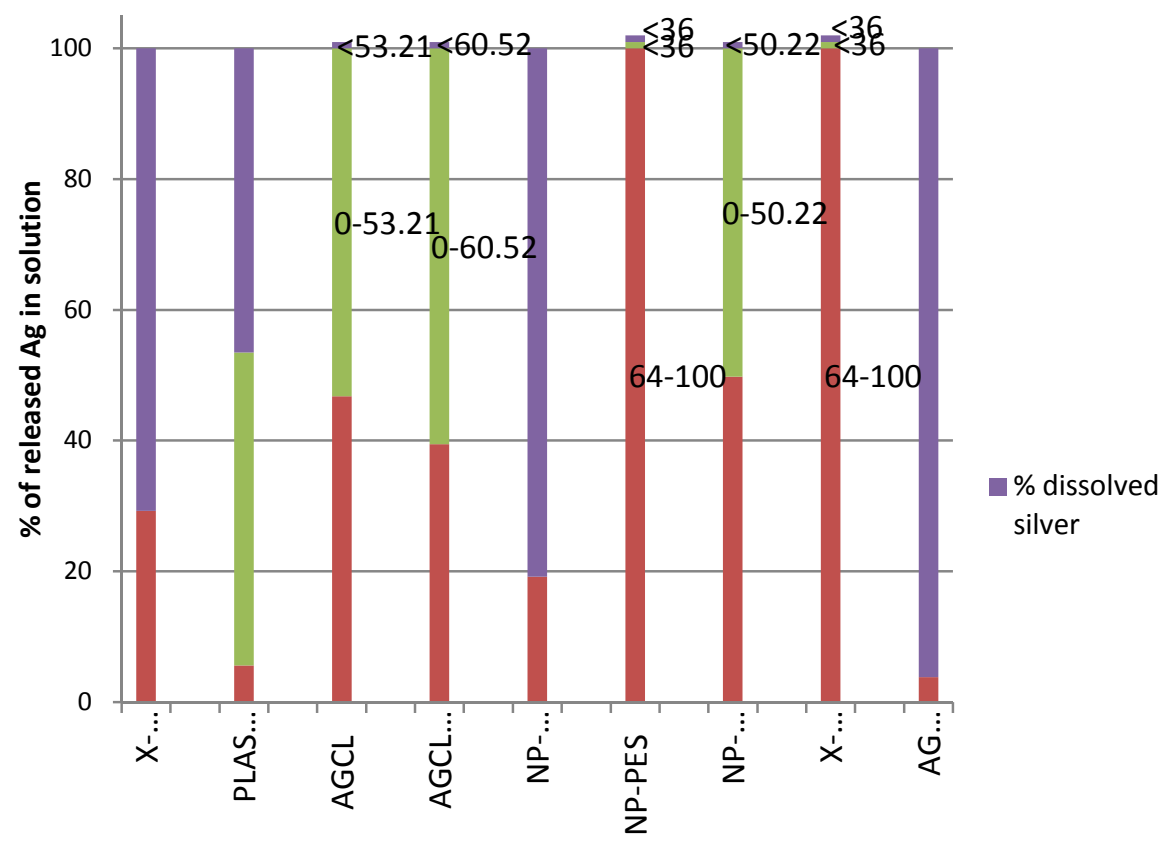

Figure 11- fractions of total silver released after 150 minutes of textile immersion and addition of PAA (0.1 mM in solution). The expression "< percentage number" represents the $\%$ released based on the detection limit of the methods (ISE or ICP-OES).

\subsection{Release of $\mathrm{Ag}$ into solution after repeated washes and $\mathrm{pH}$ changes $\mathrm{(pH} \mathrm{10-} \mathrm{pH}$} 7)

Figure 12 and 13 show the rate of $\mathrm{Ag}$ release into solution over time for two textiles. The blue arrow indicates the point-time of the transfer of the textile from the $\mathrm{pH} 10$ to the $\mathrm{pH} 7$ solution. The three repeated washes in these two solutions for three consecutive days aimed to approach the condition in the normal washing machine cycles. For the Agkilbact ${ }^{\mathrm{TM}}$ sample (figure 12), the quantity of $\mathrm{Ag}$ measured with ISE on the $1^{\text {st }}$ day reached $2.86 \cdot 10^{-5} \mathrm{M}$ after 60 minutes $\left(23.07 \%\right.$ of the total $\mathrm{Ag}$ total textile content). The $2^{\text {nd }}$ and $3^{\text {rd }}$ day this value resulted to be $1.24 \cdot 10^{-6} \mathrm{M}$ and $5.98 \cdot 10^{-7} \mathrm{M}$ respectively (corresponding to $1 \%$ and $0.49 \%$ of the total $\mathrm{Ag}$ total textile content). The addition of $\mathrm{H}_{2} \mathrm{O}_{2}$ caused a drop in the $\mathrm{Ag}^{+}$signal on the $1^{\text {st }}$ and $2^{\text {nd }}$ day, but not on $3^{\text {rd }}$ day. The $\mathrm{Ag}$ concentration diminished by a factor of 8.3 and 1.3 after 60 minutes of exposure. On the $2^{\text {nd }}$ and $3^{\text {rd }}$ day the textile sample leached more $\mathrm{Ag}^{+}$in $\mathrm{pH} 7$ solution than in $\mathrm{pH} 10$ solution, but not on the $1^{\text {st }}$ day; a maximum concentration of $2.86 \cdot 10^{-5} \mathrm{M}$ (in $\mathrm{pH} 10$ solution after 60 minutes, before the $\mathrm{H}_{2} \mathrm{O}_{2}$ addition), $6.41 \cdot 10^{-6} \mathrm{M}$ and $3.61 \cdot 10^{-6} \mathrm{M} \mathrm{Ag}$ were measured on the $1^{\text {st }}, 2^{\text {nd }}$ and $3^{\text {rd }}$ day respectively. In the same period of time (49 minutes), in the $2^{\text {nd }}$ day, the $\mathrm{Ag}$ released into the $\mathrm{pH} 7$ solution resulted to be 5.8 times more than in $\mathrm{pH}$ 10 solution. The third day this value was 6.5 . In the $3^{\text {rd }}$ wash with the $\mathrm{pH} 10$ solution the $\mathrm{X}$-static sample released more $\mathrm{Ag}$ compared to the $1^{\text {st }}$ and $2^{\text {nd }}$ wash. A maximum release of $0.11 \mu \mathrm{mol}$ 
of $\mathrm{Ag}\left(2.26 \cdot 10^{-6} \mathrm{M}\right)$ was found in the $\mathrm{pH} 7$ solution the $1^{\text {st }}$ day. This value resulted to be 5.6 times more than in $\mathrm{pH} 10$ solution for the same period of immersion time (circa 54 minutes).

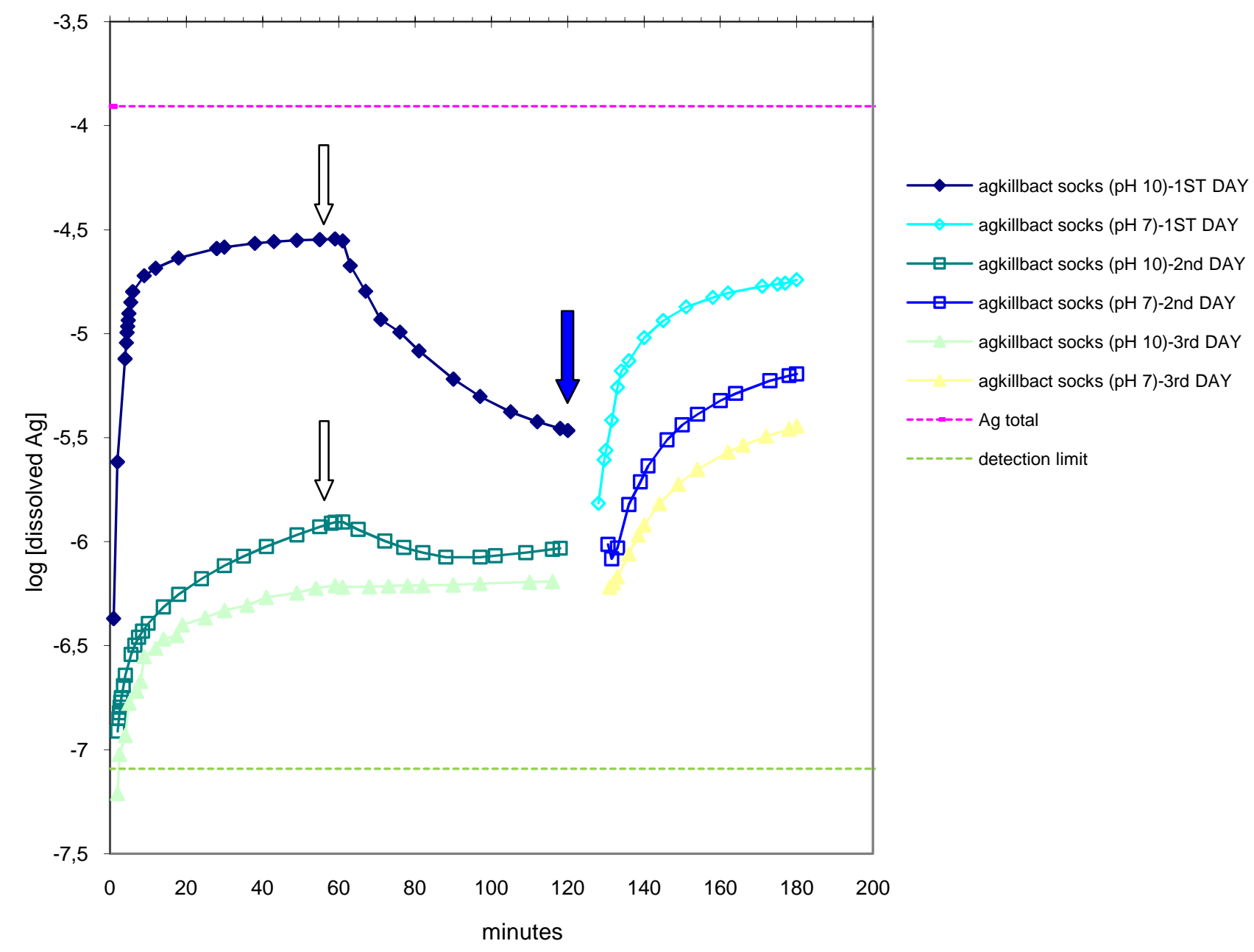

Figure 12- Agkilbact ${ }^{\mathrm{TM}}$ in $\mathrm{pH} 10$ and 7.1 solution- white arrows indicate the time-point of $\mathrm{H}_{2} \mathrm{O}_{2}$ addition (0.117 $\mathrm{mM}$ in solution) and blue arrow indicates the time-point of textile transfer from $\mathrm{pH} 10$ to $\mathrm{pH} 7$ solution. The green dashed line stands for the lowest limit of ISE calibration range (detection limit). The purple dashed line represents the total silver in the system 


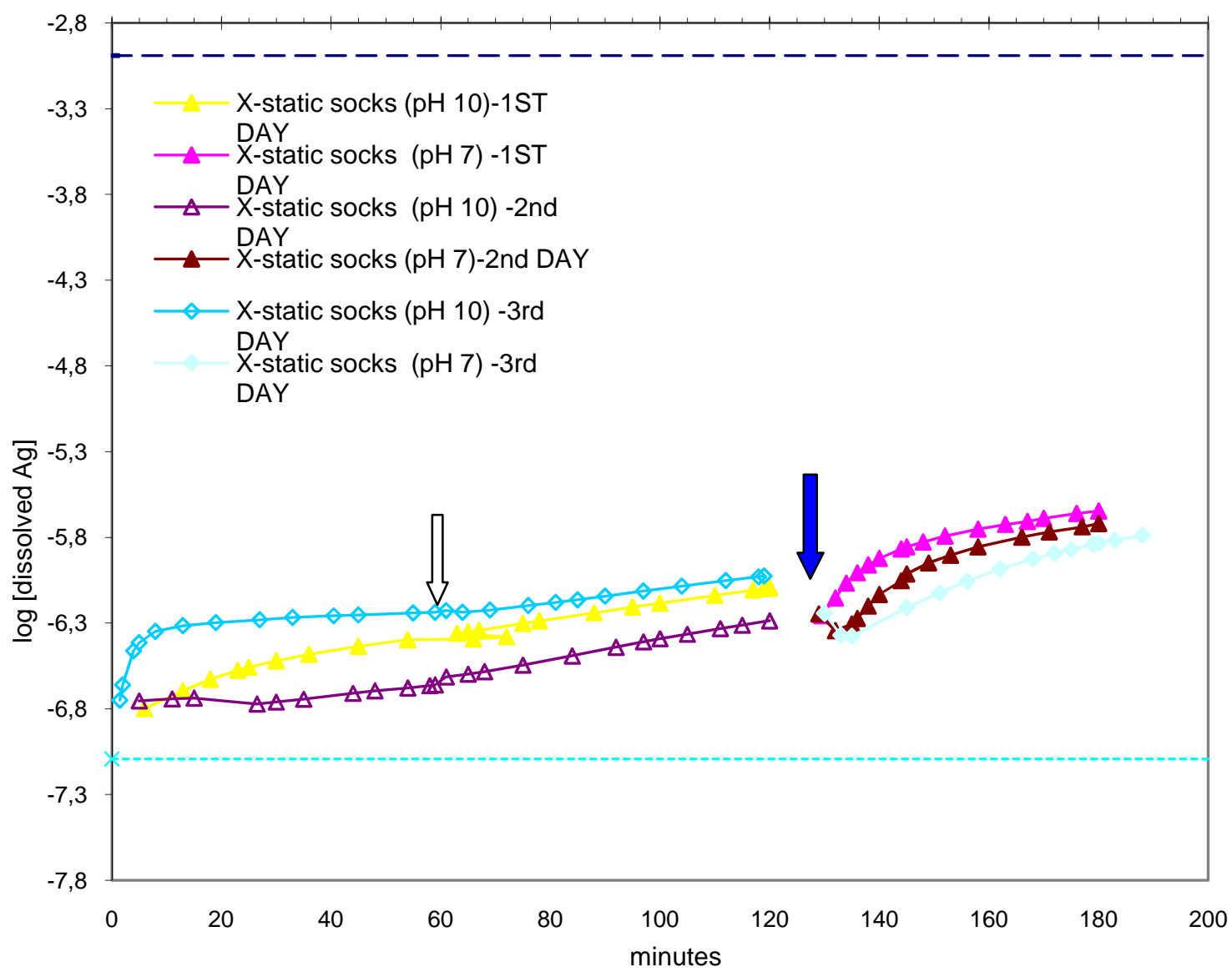

Figure 13- X-static in pH 10 and 7 solution - white arrow indicates the time-point of $\mathrm{H}_{2} \mathrm{O}_{2}$ addition $(0.117 \mathrm{mM}$ in solution) and blue arrow indicates the time-point of textile transfer from pH 10 to $\mathrm{pH} 7$ solution. The light blue dashed line stands for the lowest limit of ISE calibration range (detection limit). The dark blue dashed line represents the total silver in the system

\subsection{Silver released from textiles during washing}

Figure 14 displays the percentage of the total $\mathrm{Ag}$ in textile samples released into the washing water at the end of a washing machine run. For all the fabrics used the Ag release decreased in the $2^{\text {nd }}$ wash and for NP-PES no Ag was detected. The addition of the bleaching agent did not change significantly the distribution of the $\mathrm{Ag}$ fractions, especially the dissolved fraction. The samples NP-PES SURFACE and AGCL emitted most Ag. The amount of Ag leached in the detergent solution ranged from $6.02 \cdot 10^{-8}$ to $1.8 \cdot 10^{-5} \mathrm{M}(0.5 \mu \mathrm{g}-0.15 \mathrm{mg}$ of silver $)$ for the $1^{\text {st }}$ wash. In the successive one the concentration ranged from 0 to $5.96 \cdot 10^{-6}(0-0.05 \mathrm{mg}$ of silver). In the cycle carried out with the addition of perborate and TAED the total Ag found was 1.23.10' ${ }^{7}$ to $8.3 \cdot 10^{-6} \mathrm{M}(1 \mu \mathrm{g}-73 \mu \mathrm{g}$ of silver $)$. 


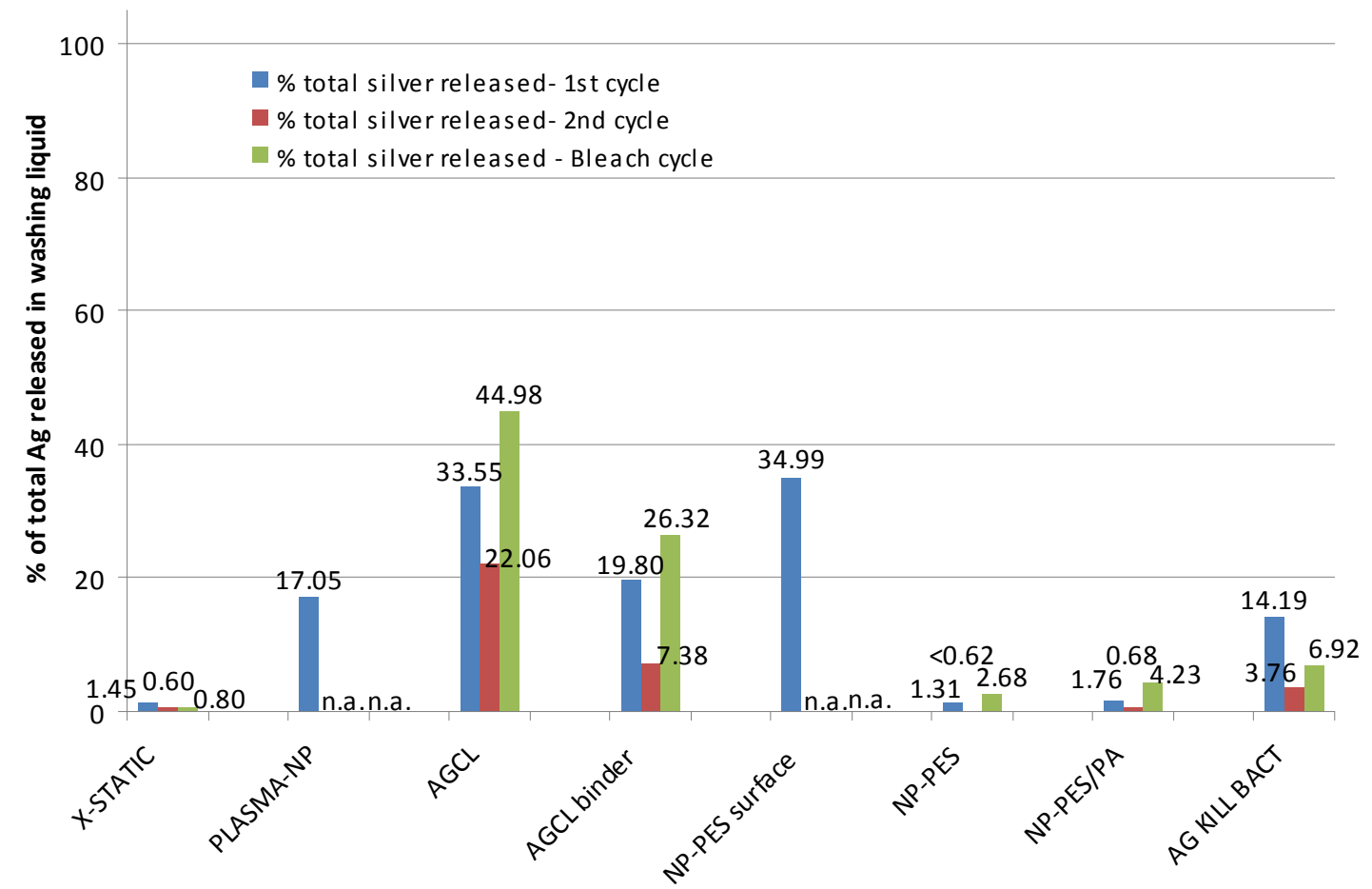

Figure $14-\%$ of total silver released in the detergent after a cycle (for the $1^{\text {st }}$ and $2^{\text {nd }}$ cycle the percentage refers to the initial Ag content of the same textile sample). No available (n.a.) data for PLASMA-NP and NP-PES surface for the second and "bleach" cycle. The table with initial Ag concentrations of the samples is attached in the appendix E-H

Figures 15, 16 and 17 show that the coarse-Ag-fraction was the most relevant in all cycles: for all the samples the range varied from 75 to $100 \%$. The PLASMA-NP sample differed from this behavior having half of the Ag leached into the washing solution in the dissolved form. For $A G C L$ and $A G C L$ BINDER samples the ionic form of $\mathrm{Ag}$ was not detected in both the washing machine and beaker tests. According to figure 8 only after the $2^{\text {nd }}$ addition of PAA $(0.5 \mathrm{mM})$ in pH 10 solution AGCL showed a low measurable concentration of silver. Given the large variance of the $\mathrm{Ag}$ content in almost all the textiles and the few measurements of the $\mathrm{Ag}$ concentration in the washing solution, it was not possible to prove the differences in the total $\mathrm{Ag}$ release between the "bleach" and the $1^{\text {st }}, 2^{\text {nd }}$ cycle. At a first glance no big relative difference, concerning the Ag-size-classes, was observed between conventional silver containing textile (e.g. X-static) and the Ag-NP fabrics (except the PLASMA-NP sample). The dissolved silver was measured (in both the beaker and washing machine test) in four out of eight fabrics tested, that is X-Static, Agkilbact ${ }^{\mathrm{TM}}$, PLASMA-NP and NP-PES SURFACE. As explained in the section 3.3, given the very low $\mathrm{Ag}$ content of some textile samples, some considerations have to be made upon the percentage of Ag-classes. For example, for the NP-PES sample, 49\%, 100\% and $24 \%$ 
of the Ag-fraction in figure 15,16 and 17 respectively, could account for whatever form of silver. In figure captions are added more information about the analysis uncertainties.

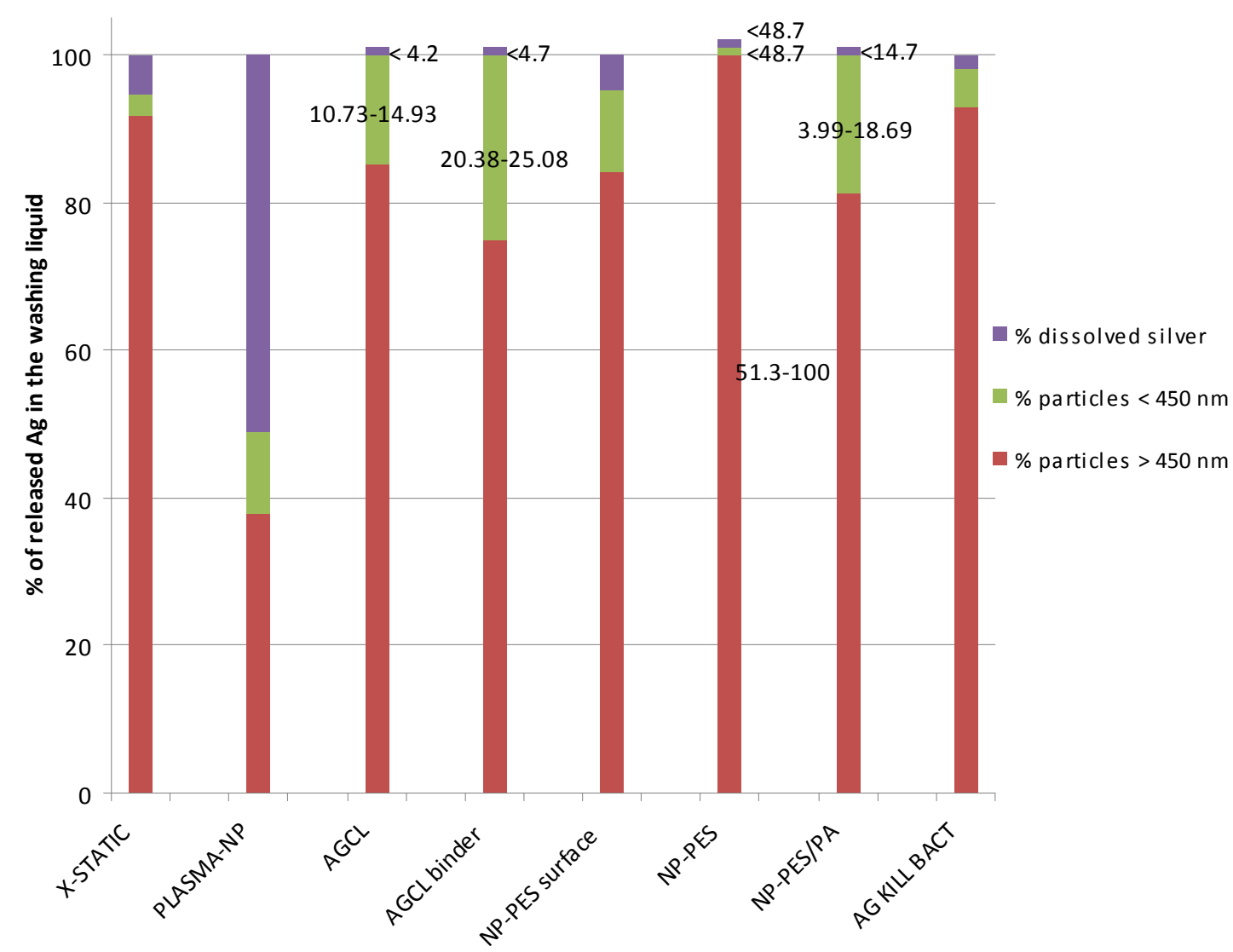

Figure 15- fractions of total $\mathrm{Ag}$ released in the detergent after the $1^{\text {st }}$ cycle (see also appendix F. For PLASMANP and NP-PES surface see appendix E). 1The expression "< percentage number" represents the \% released based on the detection limit of the methods (ISE or ICP-OES). 


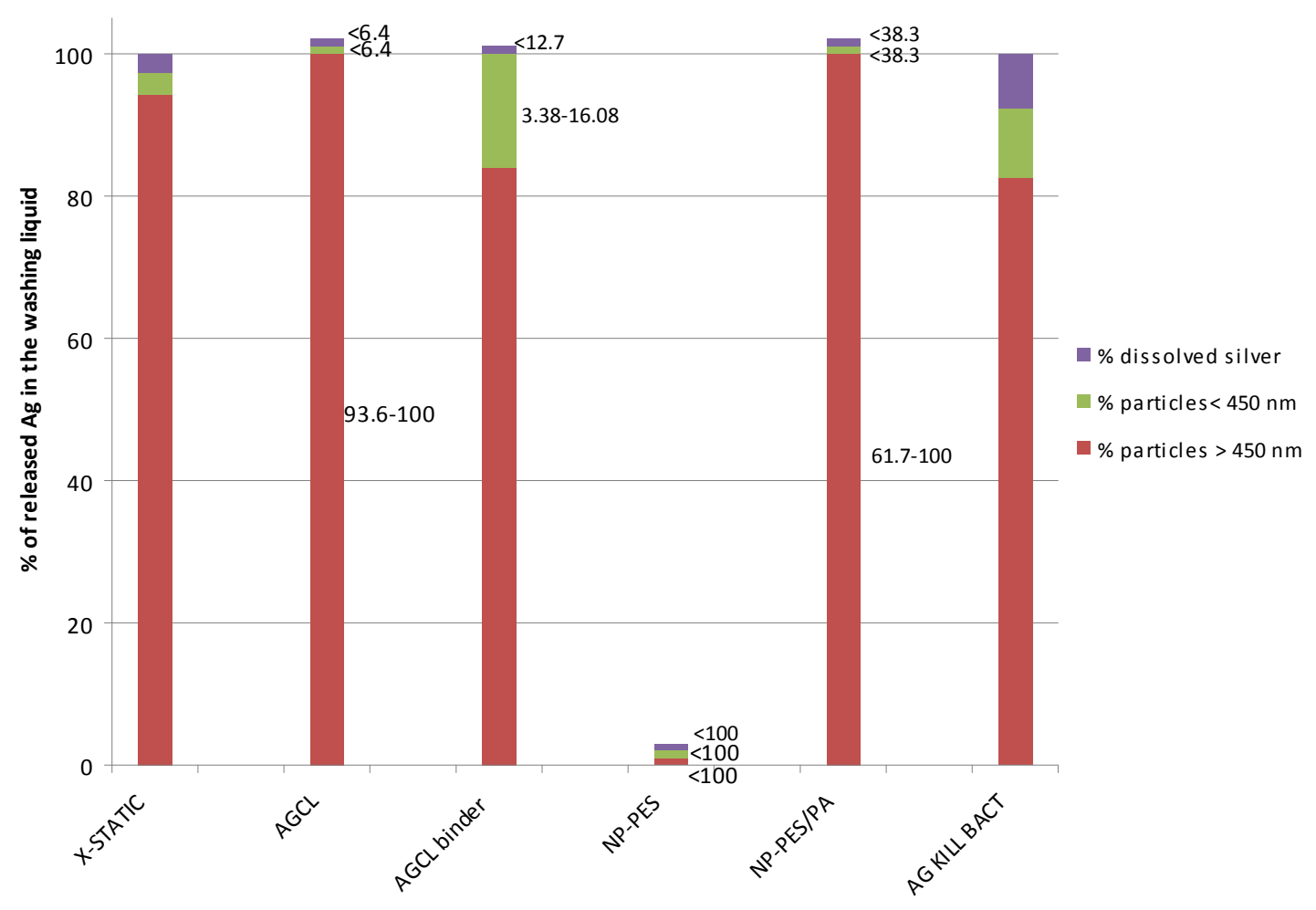

Figure16- fractions of total $\mathrm{Ag}$ released in the detergent after the $2^{\text {nd }}$ cycle. The expression " $<$ percentage number" represents the \% released based on the detection limit of the methods (ISE or ICP-OES). 


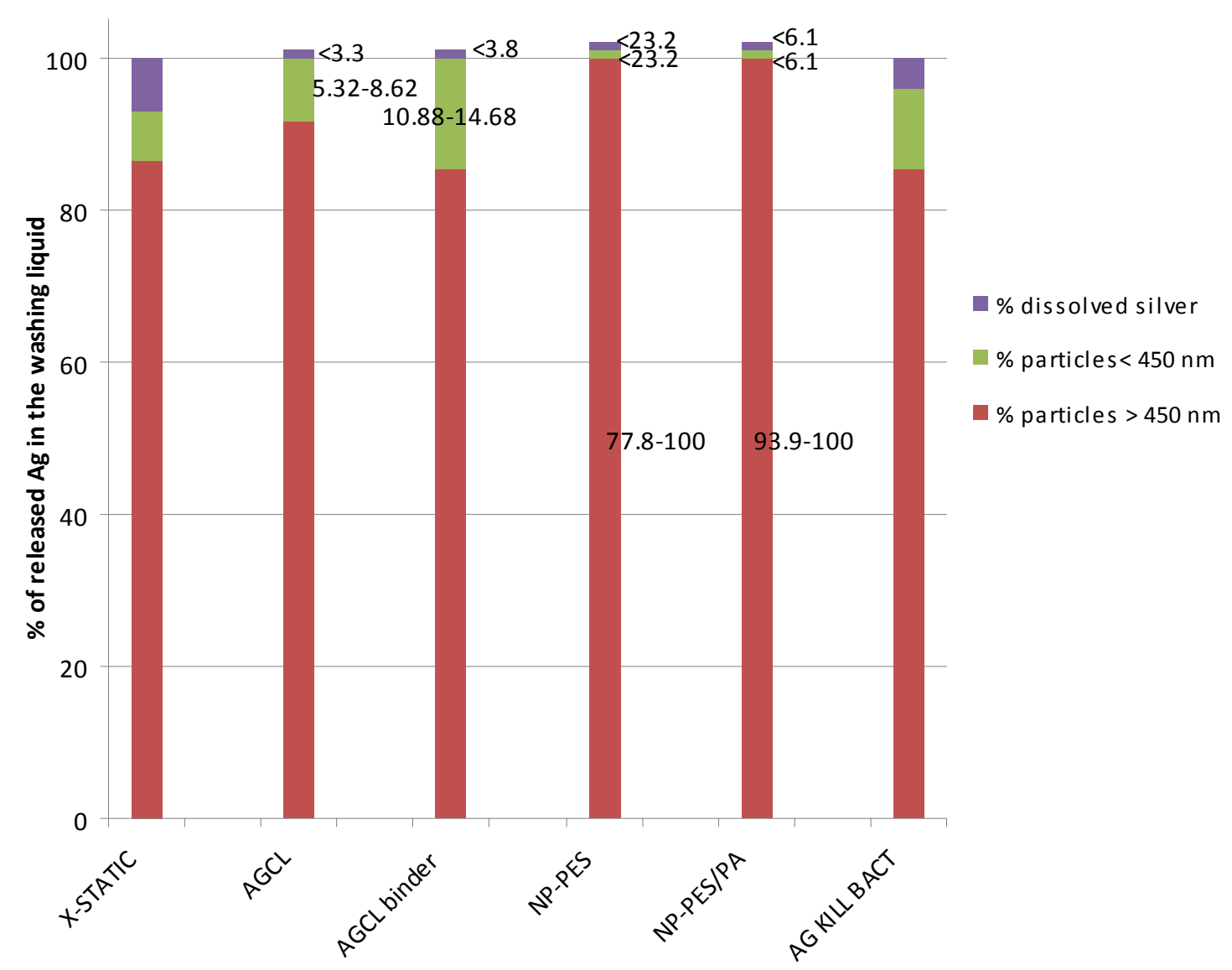

Figure17- fraction of total silver released in the detergent after the cycle with bleach. The expression "< percentage number" represents the \% released based on the detection limit of the methods (ISE or ICP-OES). 


\section{4- Discussion}

The Ag-NPs used in the experiments underwent oxidation by the general following mechanism:

1) $\mathrm{Ag}^{(0)}+$ oxidant $\rightarrow \mathrm{Ag}^{+}+$oxidant $_{\text {reduced }}$

Zero-valent Ag-NPs first have to be oxidized to release $\mathrm{Ag}^{+}$. On the other hand $\mathrm{Ag}^{+}$could be already present on the nanoparticle surface as residue of the Ag-NP chemical synthesis. AgNPs are extremely sensitive to oxygen and the antibacterial activity is probably related to their partially oxidized surface [9] (reaction 2). The chemisorbed $\mathrm{Ag}^{+}$formed can be delivered once in contact with water [17] (reaction 3).

2) $\mathrm{Ag}^{(0)}+\mathrm{O}_{2} \rightarrow \equiv \mathrm{Ag}^{+}$in water or air

3) $\equiv \mathrm{Ag}^{+} \rightarrow \mathrm{Ag}^{+}{ }_{(\mathrm{aq})}$

Since the beginning of the last century sodium perborate (SPB) has been employed as a bleaching compound in laundry detergent. SPB degrades in aqueous solution and produces hydrogen peroxide which is the oxidant agent.

4) $\mathrm{Na}_{2}\left(\mathrm{H}_{4} \mathrm{~B}_{2} \mathrm{O}_{8}\right)+4 \mathrm{H}_{2} \mathrm{O} \rightarrow 2 \mathrm{Na}\left[\mathrm{B}(\mathrm{OH})_{4}\right]+2 \mathrm{H}_{2} \mathrm{O}_{2}$

SPB is only active at temperature above $80{ }^{\circ}$ [18]. Once the hydrogen peroxide is formed, it dissociates in basic conditions as follows:

4a) $\mathrm{H}_{2} \mathrm{O}_{2}+\mathrm{OH}^{-} \leftrightarrow \mathrm{HOO}^{-}+\mathrm{H}_{2} \mathrm{O}\left(\mathrm{pKa}=11.5-11.6\right.$ at $\left.25^{\circ} \mathrm{C}\right) \quad[18-20]$

At present the perhydroxyl anion in 4a) is the accepted reactive specie responsible for the bleaching process via the ionic mechanism by nucleophilic attack on electrophilic centers [21]. he overall irreversible decomposition of hydrogen peroxide, strongly catalyzed by transition metal ions especially under alkaline conditions is the following:

4b) $2 \mathrm{H}_{2} \mathrm{O}_{2} \rightarrow \mathrm{O}_{2}(\mathrm{~g})+2 \mathrm{H}_{2} \mathrm{O}[22]$.

$\mathrm{H}_{2} \mathrm{O}_{2}$ reacts in water with silver to produce free radical species:

5) $\mathrm{Ag}(\mathrm{s})+\mathrm{H}_{2} \mathrm{O}_{2} \rightarrow \mathrm{Ag}^{+}{ }_{(\mathrm{aq})}+\mathrm{OH} \cdot+\mathrm{OH}^{-}[23]$

$\mathrm{OH}$. can further dissolve the Ag-NPs as inferred by the experiment in $\mathrm{pH} 7$ solution where $\mathrm{Ag}^{+} /$ $\mathrm{H}_{2} \mathrm{O}_{2}$ ratio was 1.73 after 240 minutes from the $\mathrm{H}_{2} \mathrm{O}_{2}$ addition. This ratio was $\sim 1$ after 60 minutes for the NP-suspension and the NP-powder with no surfactant. 
The oxidation of Ag-NPs by the hydroxyl radical at $\mathrm{pH} 4$ has been described [24]:

6) $(\mathrm{Ag})_{\mathrm{n}}+\mathrm{OH} \cdot \rightarrow \mathrm{Ag}^{+}{ }_{(\mathrm{aq})}+\mathrm{OH}^{-}$

More $\mathrm{Ag}^{+}$was released (and also more Ag-NP dissolved by $\mathrm{H}_{2} \mathrm{O}_{2}$ ) in $\mathrm{pH} 7$ than in $\mathrm{pH} 10$ solution for both the two type of Ag-NP used. This fact is in accordance with 6). A series of side

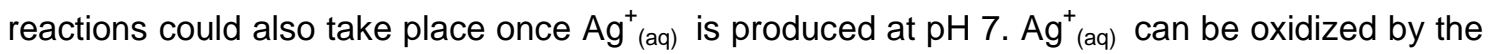
hydroxyl radical generated if enough dissolved $\mathrm{H}_{2} \mathrm{O}_{2}$ is present in solution.

7) $\mathrm{Ag}^{+}{ }_{(\mathrm{aq})}+\mathrm{OH} \cdot \rightarrow \mathrm{Ag}^{2+}{ }_{(\mathrm{aq})}+\mathrm{OH}^{-}$

Then $\mathrm{Ag}^{2+}{ }_{(\text {aq) }}$ could in turn react with $\mathrm{H}_{2} \mathrm{O}_{2}$ according to 8):

8) $\mathrm{Ag}^{2+}{ }_{(\mathrm{aq})}+\mathrm{H}_{2} \mathrm{O}_{2} \rightarrow \mathrm{Ag}^{+}{ }_{(\mathrm{aq})}+\mathrm{H}^{+}+\mathrm{H}_{2} \mathrm{O} \cdot[23]$

A decrease of the free $\mathrm{Ag}^{+}$concentration was observed in $\mathrm{pH} 10$ solution after the addition of $\mathrm{H}_{2} \mathrm{O}_{2}$ (in absence of $\mathrm{Ag}-\mathrm{NPs}$ ). Keeping all the other conditions the same, the rate of free $\mathrm{Ag}$ disappearance is faster and more pronounced when the initial $\mathrm{Ag}^{+}$concentration is higher. The $\mathrm{pH}$ measured at the beginning and at the end of the experiment was always $\sim 10$ and thus precipitation of an $\mathrm{Ag}(\mathrm{I})_{2} \mathrm{O}$ precipitate is not likely.

An explanation for the precipitation is that at high $\mathrm{pH}$ hydrogen peroxide reduces $\mathrm{Ag}^{+}$to form metallic silver which precipitates and initiates the hydrogen peroxide catalytic decomposition [25]. However it is further claimed that the precipitation to occur needs the initial presence of metallic silver and that argentic hydroxide $\left(\mathrm{Ag}(\mathrm{OH})_{2}\right.$ could be another possible candidate as precipitate because of its low solubility. However, as alternatively mechanism an oxidationreduction cycle between metal and the argentic state is not excluded [25].

Over the years bleaching activators able to activate SPB at low temperature (30-60 ${ }^{\circ}$ ) have been developed. Today one of the most used bleaching activator is tetraacetyl ethylene diamine (TAED). The reaction of TAED with the hydrogen peroxide anion in basic media forms peroxyacetic acid which is a more active bleaching agent than hydrogen peroxide $[18,20]$.

9) $\mathrm{TAED}+2 \mathrm{HOO}^{-} \rightarrow 2 \mathrm{PAA}+\mathrm{DAED}[26,27]$

Increasing the alkalinity of the medium, the rate of PAA formation increase too [20]. The PAA formed by 9 ) is not stable under the condition of its formation and it is decomposed to oxygen and acetic acid (base-catalized reaction).

10) $2 \mathrm{CH}_{3}-\mathrm{CO}-\mathrm{OO}^{-} \rightarrow 2 \mathrm{CH}_{3}-\mathrm{COO}^{-}+\mathrm{O}_{2} \cdot[18]$

So far it is not known whether peracetic acid, peracetate anion, or both acid and anion together are the active bleaching species [21]. Hofmann claims that the real bleaching agent would be the singlet oxygen formed from the peroxy acid decomposition (reaction 10). 
The $1^{\text {st }}$ and $2^{\text {nd }}$ PAA additions produced $\mathrm{Ag}^{+}$with $\mathrm{Ag}^{+} / \mathrm{PAA}$ ratio of 1.8 and 1.5 in 60 minutes respectively. PAA therefore dissolved the $\mathrm{Ag}$ equivalent to the reaction with $\mathrm{H}_{2} \mathrm{O}_{2}$ as follows:

11) $\mathrm{Ag}(\mathrm{s})+\mathrm{PAA} \rightarrow \mathrm{Ag}^{+}{ }_{(\mathrm{aq})}+\mathrm{OH} \cdot+\mathrm{OH}^{-}$

The hydroxyl radical formed can then further react as given in 6). PAA, however, was not able to oxidize $\mathrm{Ag}^{+}$and no precipitate or disappearance of the $\mathrm{Ag}^{+}$signal was observed at $\mathrm{pH} 10$ in the presence of PAA.

Perborate $(7.2 \mathrm{mM})$ and TAED together $(0.68 \mathrm{mM})$ oxidized the Ag-NPs (NP-powder) as well: the free $\mathrm{Ag}^{+}$concentration reached first a maximum and then decreased slightly. The huge difference between the combination of these two compounds and perborate alone also suggests the kinetic predominance of the Ag-NP oxidation by PAA rather than hydrogen peroxide. The decrease of the free $\mathrm{Ag}^{+}$concentration after the peak could be explained by the consumption of PAA in the reaction and by the excess of hydrogen peroxide built up over time (because of the perborate decomposition and the exhaustion of TAED). The addition of only perborate at $40{ }^{\circ} \mathrm{C}$ is not effective on Ag-NP dissol ution. Over time more hydrogen peroxide is formed and the reaction with the free $\mathrm{Ag}^{+}$became more important and resulted in disappearance of dissolved Ag.

The long term release of $\mathrm{Ag}^{+}$from polymer fibers depends to different factors including diffusion of water into the polymer, the nature and grade of crystallinity of the filler carrying $\mathrm{Ag}^{+}$, time of soaking in water, polarity of the polymer matrix, etc [10, 17, 28, 29]. During washing the synergistic effects of chemical agents and the mechanical stress can enhance the Ag release from textile. A comparison of the fabric samples indicates that the manufacturing processes of the textiles plays a relevant role in the amount of silver leached into wash water. For instance, $X$-static socks, containing a relatively large amount of $\mathrm{Ag}(0.92 \mathrm{mM}-0.1 \mathrm{mM}$ in solution), leached very small percentage $(<1.5)$ of its total silver in both the washing machine and the beaker tests. Oppositely NP-PES SURFACE and AGCL lost about $34 \%$ of their silver content after only one washing machine cycle. If the rate of Ag release from X-static would remain the same for all the life of the product, this fabric could be problematic from a disposal point of view because of the large amount of $\mathrm{Ag}$ still present in the fiber. All the textile samples tested in the washing machine seem to release silver at a lower rate in the second wash. In general the conventional Ag-textile X-Static did not show big differences in the behavior with respect to the Ag-NP textile tested during washing in the washing machine (except the PLASMA-NP sample which released half amount of the total $\mathrm{Ag}$ in the dissolved form). The addition of the bleaching agent and the bleach activator in one cycle did not seem to change significantly the relative percentage of the Ag-size classes. Since PAA and the combination of perborate/TAED dissolved very rapidly the Ag-NPs, it is reasonable to say that the access to them in the textile tested is hindered and that the reactive species produced are also scavenged by the textile fiber itself. 
The $\mathrm{Ag}^{+}$diffusion out of textile polymer of NP-PES seemed to be prevented or alternatively the time of water contact was not sufficient for an appreciable release. $\mathrm{No}^{+}$ions were detected in solution, even after the oxidant addition $\left(\mathrm{H}_{2} \mathrm{O}_{2}\right)$. From the analysis of the Ag-size classes present in the detergent solution, this sample did not even show silver release in ionic or NPs form in all the washing machine cycles (please consider the uncertainties explained in section 3.3). In a similar way dissolved $\mathrm{Ag}$ (less than $0.26 \%$ of the initial Ag concentration) was not measured for NP-PES/PA sample in all the trials performed. In both the previous fabrics the AgNPs were incorporated into the polymer.

The readily and abundant leaching of $\mathrm{Ag}$ from Agkilbact ${ }^{\mathrm{TM}}$ socks in the beaker experiment suggests that maybe $\mathrm{Ag}^{+}$was already present and chemiabsorbed on the Ag-NP surface as a residue of the Ag-NP synthesis. This fact is also suggested by the lower rates of $\mathrm{Ag}$ release in consecutive washes, which could exclude the presence of $\mathrm{Ag}$ in the textile in form of salt (e.g. $\mathrm{AgNO}_{3}$ ). Alternatively $\mathrm{Ag}$ could be in salt form outside and inside the fiber where the water could have less access.

Large differences in the Ag-size classes were found upon immersion in water. Samples like Agkilbact $^{\mathrm{TM}}$ released almost all dissolved Ag. On the contrary NP-PES only released Ag in the coarse-Ag-size-class. This large variability of the Ag form is somewhat masked in the washing machine test where the predominant fraction turned out to be the largest fraction. The way of Ag-NPs incorporation onto the polymer fiber or into the polymer matrix seemed to play a role on the Ag-fractions only in the beaker experiments. When immersed for longer time and in less drastic condition compared to the washing machine test, the textile samples displayed disparate behaviors.

It is also worthy to mention that the Agkilbact ${ }^{\mathrm{TM}}$ sample released more $\mathrm{Ag}$ in the beaker test than in the washing machine trial, but the immersion time was more than 3 times longer. All the other textiles emitted more $\mathrm{Ag}$ in the washing machine than in the beaker test, especially AGCL, AGCL BINDER and NP-PES surfaces.

AGCL BINDER, PLASMA-NP and NP-PES SURFACE have the Ag-NPs embedded into a binder/coating covering the fiber. For these samples the influence of the binder nature (e.g. grade of crystalinity or hydrophilicity) on the Ag release seems evident. In fact on a relative basis NP-PES SURFACE leached considerably more Ag than PLASMA-NP and AGCL BINDER and mostly in the dissolved form. On the other hand the PLASMA-NP textile released Ag mainly in the particulate fraction passing the $0.45 \mu \mathrm{m}$ filter, which was half dissolved after the PAA addition. Presumably this sample first released available Ag-NP in solution which were then oxidized rapidly by the PAA. Contrarily in the AGCL BINDER sample, it seems that $\mathrm{AgCl}$ crystals did not release detectable $\mathrm{Ag}^{+}$(less than $2.5 \%$ of the initial $\mathrm{Ag}$ concentration). Moreover the particles size classes did not relevantly change in percentage, fact that could also indicate that the access of water into the Ag-NP binder is set back. Although AGCL has the $\mathrm{AgCl}$ 
crystals on the cotton fibers surface, the total silver release is no relevantly different from AGCL BINDER where the $\mathrm{AgCl}$ particles are embedded inside a coating on the fiber surface. The uncertainty resides in the fraction passing the $0.45 \mu \mathrm{m}$ filter, which could be very dissimilar. On the other hand in the washing machine experiment this difference in the total silver leached is more accentuated and the Ag fraction passing the $0.45 \mu \mathrm{m}$ filter did not contain detectable $\mathrm{Ag}$ in the dissolved form (less than $1.5 \%$ ).

The rate of $\mathrm{Ag}$ release for the $\mathrm{X}$-static textile is enhanced once placed into $\mathrm{pH} 7$ solution after exposure at $\mathrm{pH}$ 10. The Agkilbact ${ }^{\mathrm{TM}}$ presents the same behavior as X-Static in the $2^{\text {nd }}$ and $3^{\text {rd }}$ wash (figure 12). From these results, the water at $\mathrm{pH} 7$ seems to be more aggressive in stripping silver from the two brand socks sampled. As a final information, table 2 reports the micrograms of Ag released in the washing solution per grams of textile.

Table 2- $\mu \mathrm{g}$ of total Ag released/ $\mathrm{g}$ of textile- washing machine test

\begin{tabular}{llll}
\hline & 1st cycle & 2nd cycle & Bleach cycle \\
\hline X-Static & 314.25 & 129.12 & 172.30 \\
PLASMA-NP & 66.51 & - & - \\
AGCL & 2.68 & 1.76 & 3.60 \\
AGCL binder & 2.38 & 0.89 & 3.16 \\
NP-PES surface & 10.15 & - & - \\
NP-PES & 1.29 & 0.35 & 2.66 \\
NP-PES/PA & 4.26 & 1.64 & 10.24 \\
AG KILL BACT & 377.51 & 99.91 & 183.95 \\
\hline
\end{tabular}




\section{5- Conclusion}

In this thesis various fabrics with different configuration and way of Ag-NP incorporation into the polymer were studied during washing. This work represents a first attempt to evaluate the amount and the form of $\mathrm{Ag}$ released from these textiles. Systematic and repeated washes for each fabric type are needed in order to prove the trend found in this analysis. In general the percentage of the total silver content emitted from the textiles tested varied consistently among products (from less than $1 \%$ to $45 \%$ ). This difference is already clear after only one or two cycles. This first insight showed that silver in the particulate fraction $>0.45 \mu \mathrm{m}$ is probably the predominant form released from the textile tested during the washing. The composition and characterization of this coarse-Ag-fraction (that could include Ag precipitates, large Ag-NPs aggregates, $\mathrm{Ag}$ in fiber particles) are the next steps for future researches. In addition its behavior once in the environmental water will have to be carefully study. At the moment the big uncertainties are whether the Ag in this coarse fraction will be readily dissolved and if it will be easily remove by WWTP or not. However the removal of this fraction from wastewater will not exclude, in a long term prospective, the threat for agricultural lands and terrestrial organisms. Generally in the washing machine test the nano-silver materials seemed to relatively release dissolved Ag in a small fraction.

From a toxicological point of view, further studies about the relevant species of silver in surface water, especially silver sulfide and free silver ions, are needed [2]. Besides, the bioavailability of silver nanoparticles in natural water, which is related to particles aggregation, deposition, dispersion and dissolution, has to be considered [30]. Moreover the concentration of silver and the determination of its prevalent forms in soils is required for assessing the toxicological effect on the terrestrial organisms [2]. New analytical methods for detecting and quantifying low Ag-NP concentrations in environmental matrices are still lacking.

Finally further investigations are necessary to prove the composition of the precipitate observed after the addition of $\mathrm{H}_{2} \mathrm{O}_{2}$ in the $\mathrm{AgNO}_{3}$ standard solution at $\mathrm{pH} 10$. 


\section{6- Acknowledgements}

I gratefully thank my supervisor PD Dr. Bernd Nowack for having given me the opportunity to undertake my master thesis at EMPA. I further thank him for his precious and constant advises and support in all the phases of my permanence at the institute. I also really appreciated the warm atmosphere in the whole group. I am grateful to Dr. Manfred Heuberger for his insights and Elisabeth Michel for her help in part of my laboratory work.

We also acknowledge Dr. Murray Height from HeiQ Materials AG and Dr. Harald Lutz from CHT R. BEITLICH GMBH for providing textile samples and product-related data. We further thank HeiQ Materials AG for the silver analysis of some textile samples.

Finally we express gratitude to Dr. Renata Behra (from EAWAG aquatic research institute) for supplying Ag-NP suspension from NanoSys. 


\section{7- References}

1. Woodrow Wilson Institute. An inventory of nanotechnology-based consumer products currently on the market. http://www.nanotechproject.org In 2008.

2. Blaser, S. A.; Scheringer, M.; MacLeod, M.; Hungerbuhler, K., Estimation of cumulative aquatic exposure and risk due to silver: Contribution of nano-functionalized plastics and textiles. Science of the Total Environment 2008, 390, (2-3), 396-409.

3. Morones, J. R.; Elechiguerra, J. L.; Camacho, A.; Holt, K.; Kouri, J. B.; Ramirez, J. T.; Yacaman, M. J., The bactericidal effect of silver nanoparticles. Nanotechnol. 2005, 16, (10), 2346-2353.

4. Kim JS, Kuk E, Yu KN, Kim JH,Park SJ,Lee HJ,KIM SH, Park YH,Hwang CY,Kim YK, Lee Ys, Jeong DH,Cho MH, Antimicrobial effects of silver nanoparticles. Nanomedicine: Nanotechnology, Biology and Medicine 2007, 3, (1), 95-101.

5. Sondi, I.; Salopek-Sondi, B., Silver nanoparticles as antimicrobial agent: a case study on E.coli as a model for Gram-negative bacteria. J. Colloid Interface Sci. 2004, 275, (1), 177182.

6. Yoon, K. Y.; Byeon, J. H.; Park, J. H.; Hwang, J., Susceptibility constants of Escherichia coli and Bacillus subtilis to silver and copper nanoparticles. Sci. Total Environ. 2007, 373, (2-3), 572-575.

7. Ratte, H. T., Bioaccumulation and toxicity of silver compounds: a review. Environmental toxicology and Chemistry 1999, 18, (1), 89-108.

8. Enrique Navarro, Flavio Piccapietra, Bettina Wagner, Fabio Marconi, Ralf Kaegi, Niksa Odzak, Laura Sigg and Renata Behra, Toxicity of Silver Nanoparticles to Chlamydomonas reinhardtii. Environmental Science and Technology 2008, 42, (23), 8959-8964.

9. Chun-Nam Lok ${ }^{1,3}$, Chi-Ming Ho, ${ }^{1,2}$, Rong Chen ${ }^{1,2}$, Qing-Yu He ${ }^{1,2}$, Wing-Yiu $\mathrm{Yu}^{1,2}$, Hongzhe Sun ${ }^{1,2}$, Paul Kwong-Hang Tam ${ }^{4}$, Jen-Fu Chiu, ${ }^{1,3}$ and Chi-Ming Che ${ }^{1,2}$ Silver nanoparticles: partial oxidation and antibacterial activities. Journal of Biological Inorganic Chemistry 2006, 12, (4), 527-534.

10. Kumar, R.; Howdle, S.; Munstedt, H., Polyamide/silver antimicrobials: Effect of filler types on the silver ion release. Journal of Biomedical Materials Research Part B-Applied Biomaterials 2005, 75B, (2), 311-319.

11. Bruce Gibbins, Lenna Warner, The Role of Antimicrobial Silver Nanotechnology. Medical Device \& Diagnostic Industry 2005.

12. Luoma, Samuel N. Silver Nanotechnologies and the environment: old problems or new challenges?; Woodrow Wilson International Center for Scholars 2008.

13. Lok, C. N.; Ho, C. M.; Chen, R.; He, Q. Y.; Yu, W. Y.; Sun, H.; Tam, P. K. H.; Chiu, J. F.; Che, C. M., Silver nanoparticles: partial oxidation and antibacterial activities. J. Biol. Inorg. Chem. 2007, 12, (4), 527-534.

14. Troy M. Benn, Paul Westerhoff Nanoparticle Silver Released into Water from Commercially Available Sock Fabrics. Environmental Science and Technology 2008, 42, (11), 4133-4139.

15. Mueller, N. C.; Nowack, B., Exposure modeling of engineered nanoparticles in the environment. Environ. Sci. Technol. 2008, 42, 4447-4453.

16. Pinkernell Ulrich, Lüke Hans-Joachim, Karst Uwe, Selective Photometric Determination of Peroxycarboxylic Acids in the Presence of Hydrogen Peroxide. The Analyst 1997, 122, (6), 567-571.

17. Damm, C.; Munstedt, H., Kinetic aspects of the silver ion release from antimicrobial polyamide/silver nanocomposites. Applied Physics a-Materials Science \& Processing 2008, 91, (3), 479-486. 
18. Joerg Hofmann, Gerhard Just, Wilhelm Pritzkow and Harald Schmidt, Bleaching Activators and the Mechanism of Bleaching Activation. Journal fuer praktische Chemie 1992, 334, 293-297.

19. RunCang Sun, J. Tomkinson, F.C. Mao, X.F. Sun, Physicochemical Characterization of Lignins from Rice Straw by Hydrogen Peroxide Treatment. Journal of Applied Polymer Science 2001, 79, (4), 719-732.

20. H.G. Hauthal, H.Schmidt, H.J. Scholz, J. Hofmann und W.Pritzkow, Studies Concerning the Mechanism of Bleaching activation. Tenside Surfactants Detergent 1990, 27, (3), 187-193.

21. J.Milne, Neal, Oxygen Bleaching Systems in Domestic Laundry. Journal of Surfactants and Detergents 1998, 1, (2), 253-261.

22. Clement, Daniel, The Blistering of paper during hydrogen peroxide bleaching. Journal of the American Institute for Conservation 1983, 23, (1), 47-62.

23. T.E.Graedel, Corrosion Mechanism for Silver Exposed to the Atmosphere. The Electrochemical Society, Inc 1992, 139, (7), 1963-1970.

24. Liang AiHui, Zhang NanNan, Jiang ZhiLiang and Liu RongJin, Nanosilver resonance scattering spectral method for determination of hydroxyl radical and its application. Science in China Serie B: Chemistry 2008, 51, (3), 226-232.

25. Walter C. Schumb, Charles N. Satterfield, Ralph L. Wentworth, Hydrogen Peroxide. Reinhold Publishing Corporation: 1955.

26. Kantouch, A.; El-Sayed, A. A., Polyvinyl pyridine metal complex as permanent antimicrobial finishing for viscose fabric. Int J Biol Macromol 2008, 43, (5), 451-5.

27. RunCang Sun, Tomkinson, Characterization of hemicelluloses isolated with tetraacetylethylenediamine activated peroxide from ultrasound irradiated and alkali pre-treated wheat straw. European Polymer Journal 2003, 39, (4), 751-759.

28. Kumar, R.; Munstedt, H., Polyamide/silver antimicrobials: effect of crystallinity on the silver ion release. Polymer International 2005, 54, (8), 1180-1186.

29. Kumar, R.; Munstedt, H., Silver ion release from antimicrobial polyamide/silver composites. Biomaterials 2005, 26, (14), 2081-2088.

30. Wiesner, M. R.; Lowry, G.V.; Alvarez, P.; Dionysiou, D.; Biswas, P., Assessing the risks of manufactured nanomaterials. Environ. Sci. Technol. 2006, 40, (14), 4336-4345. 


\section{8- Appendices}

\section{Appendix A -Example ISE calibration}

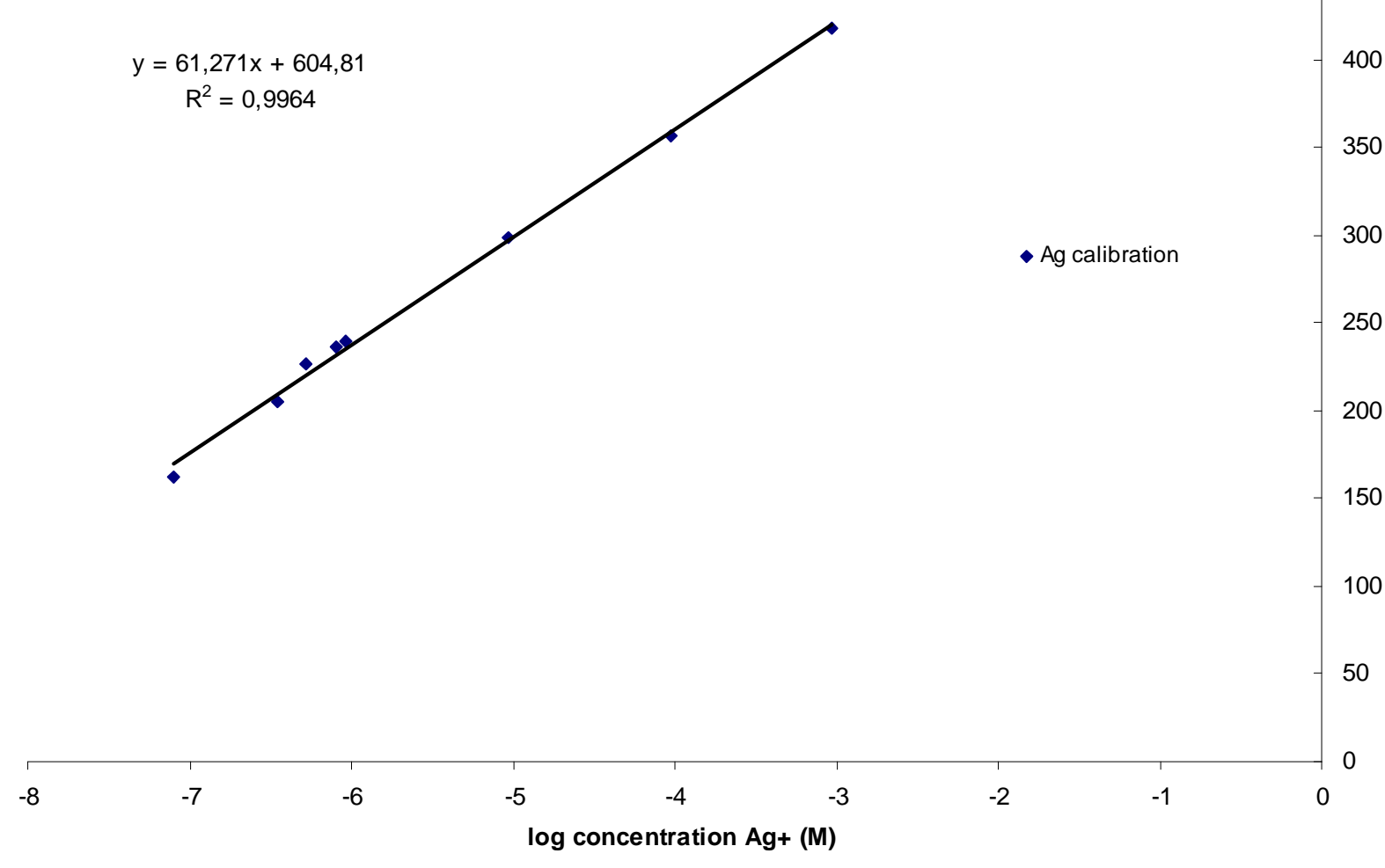


Appendix B - ECE powder composition

\section{Zusammensetzung}

Lineares Natriumalkylbenzolsulfonat (Kettenlaenge des Alkylrests: C11,5)

Ethoxylierter Talgalkohol (14 EO)

Natriumseife (Kettenlaengen $\mathrm{C}_{12}-\mathrm{C}_{16}: 13$ bis $26 \%, \mathrm{C}_{18}-\mathrm{C}_{22}: 74$ bis $87 \%$ )

Natriumtripolyphosphat

Natriumsilikat $\left(\mathrm{SiO}_{2} / \mathrm{Na}_{2} \mathrm{O}=3.3 / 1\right)$

Magnesiumsilikat

Carboxymethylcellulose (CMC)

Ethylendiamintetraessigsaeure (EDTA), Natriumsalz

Natriumsulfat

Wasser
Masseanteile in \%

$8.0 \pm 0.02$

$2.9 \pm 0.02$

$3.5 \pm 0.02$

$43.7 \pm 0.02$

$7.5 \pm 0.02$

$1.9 \pm 0.02$

$1.2 \pm 0.02$

$0.2 \pm 0.02$

$21.2 \pm 0.02$

$9.9 \pm 0.02$ 
Appendix C-Silver release experiment: sampling at 100 minutes. B.d.I (below detection limit). O.r. (Out of ISE calibration range, lowest Ag concentration $=7.95 \cdot 10^{-8} \mathrm{M}$ )

\begin{tabular}{|c|c|c|c|c|c|c|c|c|c|c|c|c|}
\hline Textile ID & $\begin{array}{l}\text { Textile } \\
\text { Mass }\end{array}$ & $\begin{array}{c}\mathrm{Ag} \\
\text { content in } \\
\text { the textile }\end{array}$ & $\begin{array}{l}\text { Total Ag } \\
\text { in the } \\
\text { system }\end{array}$ & $\begin{array}{l}\text { Total } \mathbf{A g} \\
\text { released } \\
\text { (unfiltered) }\end{array}$ & $\begin{array}{l}\text { Total } \mathrm{Ag} \\
\text { released } \\
\text { (unfiltered) }\end{array}$ & $\begin{array}{c}\mathrm{Ag}<450 \mathrm{~nm} \\
\text { (filtered) }\end{array}$ & $\begin{array}{c}\mathrm{Ag}<450 \mathrm{~nm} \\
\text { (filtered) }\end{array}$ & $\begin{array}{l}\text { Dissolved } \\
\text { Ag (ISE) }\end{array}$ & $\begin{array}{l}\text { Total } \mathrm{Ag} \\
\text { released }\end{array}$ & $\begin{array}{c}\mathrm{Ag}>450 \\
\mathrm{~nm}\end{array}$ & $\begin{array}{c}\mathrm{Ag}<450 \\
\mathrm{~nm}\end{array}$ & $\begin{array}{c}\text { Dissolved } \\
\mathrm{Ag}\end{array}$ \\
\hline & $\mathrm{mg}$ & $\mathrm{mg}$ & Molarity & Molarity & $\mathrm{mg} / \mathrm{L}$ & Molarity & $\mathrm{mg} / \mathrm{L}$ & Molarity & $\%$ & $\%$ & $\%$ & $\%$ \\
\hline X-STATIC & 260.39 & 5.624 & $1.043 \mathrm{E}-03$ & 1.307E-06 & 0.141 & 5.006E-07 & 0.054 & 7.109E-07 & 0.13 & 61.70 & 38.30 & 54.38 \\
\hline PLASMA-NP & 261.33 & 0.102 & $1.890 \mathrm{E}-05$ & 1.326E-06 & 0.143 & 1.187E-06 & 0.128 & $1.105 \mathrm{E}-07$ & 7.02 & 10.49 & 89.51 & 8.34 \\
\hline AGCL & 1238.58 & 0.010 & $1.837 \mathrm{E}-06$ & $1.136 \mathrm{E}-07$ & 0.01225 & 5.655E-08 & 0.0061 & o.r. & 6.18 & 50.20 & 49.80 & $<49.80$ \\
\hline AGCL BINDER & 1205.36 & 0.014 & $2.682 \mathrm{E}-06$ & $1.270 \mathrm{E}-07$ & 0.0137 & $6.860 \mathrm{E}-08$ & 0.0074 & o.r. & 4.74 & 45.99 & 54.01 & $<54.01$ \\
\hline NP-PES surface & 1209.02 & 0.035 & $6.501 \mathrm{E}-06$ & $8.010 \mathrm{E}-07$ & 0.0864 & $6.675 \mathrm{E}-07$ & 0.072 & 7.492E-07 & 12.32 & 16.67 & 83.33 & 93.54 \\
\hline NP-PES & 257.42 & 0.025 & 4.725E-06 & 8.344E-08 & 0.009 & 1.000E-04 & b.d.l. & o.r. & 1.77 & 100.00 & $<34$ & $<34$ \\
\hline NP-PES/PA & 248.88 & 0.060 & 1.117E-05 & 1.275E-07 & 0.01375 & $5.655 \mathrm{E}-08$ & 0.0061 & o.r. & 1.14 & 55.64 & 44.36 & $<44.36$ \\
\hline X-SYSTEMS & 1813.28 & 0.005 & $1.009 \mathrm{E}-06$ & b.d.I. & 0.0031 & b.d.l. & 0.00035 & o.r. & $<2.85 \%$ & $<100$ & $<100$ & $<100$ \\
\hline AG KILL BACT & 256.23 & 0.682 & $1.264 \mathrm{E}-04$ & 3.365E-05 & 3.63 & 2.853E-05 & 3.077 & 3.484E-05 & 26.63 & 15.23 & 84.77 & 103.53 \\
\hline
\end{tabular}


Appendix D-Silver release experiment: sampling at 150 minutes. B.d.I (below detection limit). O.r. (Out of ISE calibration range, lowest Ag concentration $=7.95 \cdot 10^{-8} \mathrm{M}$ )

\begin{tabular}{|c|c|c|c|c|c|c|c|c|c|c|c|c|}
\hline \multirow[t]{2}{*}{ Textile ID } & $\begin{array}{l}\text { Textile } \\
\text { Mass }\end{array}$ & $\begin{array}{l}\text { Ag content in } \\
\text { the textile }\end{array}$ & $\begin{array}{l}\text { Total Ag in } \\
\text { the system }\end{array}$ & $\begin{array}{l}\text { Total Ag } \\
\text { released } \\
\text { (unfiltered) }\end{array}$ & $\begin{array}{l}\text { Total } \mathrm{Ag} \\
\text { released } \\
\text { (unfiltered) }\end{array}$ & $\begin{array}{c}\mathrm{Ag}<450 \\
\mathrm{~nm} \\
\text { (filtered) }\end{array}$ & $\begin{array}{c}\mathrm{Ag}<450 \\
\mathrm{~nm} \\
\text { (filtered) }\end{array}$ & $\begin{array}{l}\text { Dissolved } \\
\text { Ag (ISE) }\end{array}$ & $\begin{array}{l}\text { Total } \mathrm{Ag} \\
\text { released }\end{array}$ & $\begin{array}{c}\mathrm{Ag}>450 \\
\mathrm{~nm}\end{array}$ & $\begin{array}{c}\mathrm{Ag}<450 \\
\mathrm{~nm}\end{array}$ & $\begin{array}{l}\text { Dissolved } \\
\text { Ag (ISE) }\end{array}$ \\
\hline & mg & mg & Molarity & Molarity & $\mathrm{mg} / \mathrm{L}$ & Molarity & $\mathrm{mg} / \mathrm{L}$ & Molarity & $\%$ & $\%$ & $\%$ & $\%$ \\
\hline X-STATIC & 260.39 & 5.624 & $1.043 \mathrm{E}-03$ & $9.827 \mathrm{E}-07$ & 0.11 & $6.953 \mathrm{E}-07$ & 0.08 & $9.551 \mathrm{E}-07$ & 0.09 & 29.25 & 70.75 & 97.19 \\
\hline PLASMA-NP & 261.33 & 0.102 & $1.890 \mathrm{E}-05$ & $1.984 \mathrm{E}-06$ & 0.214 & $1.873 \mathrm{E}-06$ & 0.202 & $9.228 \mathrm{E}-07$ & 10.50 & 5.61 & 94.39 & 46.51 \\
\hline AGCL & 1238.58 & 0.010 & $1.837 \mathrm{E}-06$ & $1.010 \mathrm{E}-07$ & 0.0109 & 5.377E-08 & 0.0058 & b.d.l. & 5.50 & 46.79 & 53.21 & $<53.21$ \\
\hline $\begin{array}{l}\text { AGCL } \\
\text { BINDER }\end{array}$ & 1205.36 & 0.014 & $2.682 \mathrm{E}-06$ & $1.080 \mathrm{E}-07$ & 0.01165 & $6.536 \mathrm{E}-08$ & 0.00705 & b.d.l. & 4.03 & 39.48 & 60.52 & $<60.52$ \\
\hline $\begin{array}{l}\text { NP-PES } \\
\text { surface }\end{array}$ & 1209.02 & 0.035 & $6.501 \mathrm{E}-06$ & $9.257 \mathrm{E}-07$ & 0.09985 & 7.481E-07 & 0.0807 & $8.973 \mathrm{E}-07$ & 14.24 & 19.18 & 80.82 & 96.94 \\
\hline NP-PES & 257.42 & 0.025 & 4.725E-06 & 7.973E-08 & 0.0086 & b.d.l. & 0.00315 & b.d.l. & 1.69 & 100.00 & $<36$ & $<36$ \\
\hline NP-PES/PA & 248.88 & 0.060 & 1.117E-05 & $1.061 \mathrm{E}-07$ & 0.01145 & 5.331E-08 & 0.00575 & b.d.l. & 0.95 & 49.78 & 50.22 & $<50.22$ \\
\hline X-SYSTEMS & 1813.28 & 0.005 & $1.009 \mathrm{E}-06$ & 7.973E-08 & 0.0086 & b.d.l. & 0.00135 & b.d.l. & 7.90 & 100.00 & $<36$ & $<36$ \\
\hline $\begin{array}{l}\text { AG KILL } \\
\text { BACT }\end{array}$ & 256.23 & 0.682 & $1.264 \mathrm{E}-04$ & $3.048 \mathrm{E}-05$ & 3.288 & $2.932 \mathrm{E}-05$ & 3.163 & $3.328 \mathrm{E}-05$ & 24.12 & 3.80 & 96.20 & 109.18 \\
\hline
\end{tabular}




\begin{tabular}{|c|c|c|c|c|c|c|c|c|c|c|c|c|c|c|c|c|c|}
\hline \multirow[t]{3}{*}{ Textile ID } & \multirow{3}{*}{$\begin{array}{c}\text { Textile Mass } \\
\text { mg }\end{array}$} & \multirow{3}{*}{$\begin{array}{c}\underset{\mathrm{Ag}}{\text { content }} \\
\mathrm{mg}\end{array}$} & \multirow{3}{*}{$\begin{array}{l}\text { Total Ag } \\
\text { in the } \\
\text { system }\end{array}$} & \multirow{3}{*}{$\begin{array}{c}\begin{array}{c}\mathrm{Ag}<450 \\
\mathrm{~nm} \\
\text { (filtered) }\end{array} \\
\\
\mathrm{mg} / \mathrm{L}\end{array}$} & \multirow{3}{*}{$\begin{array}{c}\begin{array}{c}\mathrm{Ag}<450 \\
\mathrm{~nm} \\
\text { (filtered) }\end{array} \\
\\
\text { Molarity }\end{array}$} & \multirow{3}{*}{$\begin{array}{c}\text { Ag } \\
\text { dissolved } \\
\text { (filt./centr.) } \\
\\
\text { mg/L }\end{array}$} & \multirow{3}{*}{$\begin{array}{c}\text { Ag } \\
\text { dissolved } \\
\text { (filt./centr.). } \\
\text { Molarity }\end{array}$} & \multirow{3}{*}{$\begin{array}{c}\begin{array}{c}\text { Total } \\
\text { Ag } \\
\text { release }\end{array} \\
\\
\mathrm{mg} / \mathrm{L} \\
\begin{array}{c}\text { 1st } \\
\text { aliquot }\end{array}\end{array}$} & \multirow{3}{*}{$\begin{array}{c}\text { Total } \\
\text { Ag } \\
\text { release } \\
\\
\text { mg/L } \\
\text { 2nd } \\
\text { aliquot }\end{array}$} & \multirow{3}{*}{$\begin{array}{c}\begin{array}{c}\text { Total } \\
\text { Ag } \\
\text { release }\end{array} \\
\text { mg/L } \\
\text { 3rd } \\
\text { aliquot }\end{array}$} & \multirow{3}{*}{$\begin{array}{c}\text { Total } \\
\mathrm{Ag} \\
\text { release } \\
\text { (mean) }\end{array}$} & \multirow{3}{*}{$\begin{array}{l}\text { Total Ag } \\
\text { release } \\
\text { (mean) } \\
\text { Molarity }\end{array}$} & \multirow{3}{*}{$\begin{array}{c}\text { STDV } \\
\text { total } \\
\text { Ag } \\
\text { release }\end{array}$} & \multirow{3}{*}{$\begin{array}{c}\text { STDV } \\
\text { total } \\
\text { Ag } \\
\text { release } \\
\\
\%\end{array}$} & \multirow{3}{*}{$\begin{array}{c}\text { Total Ag } \\
\text { released } \\
\\
\\
\%\end{array}$} & \multirow{3}{*}{$\begin{array}{c}\mathrm{Ag}<450 \\
\mathrm{~nm} \\
\\
\\
\quad \%\end{array}$} & \multirow{3}{*}{$\begin{array}{c}\text { Dissolved } \\
\text { Ag } \\
\\
\\
\%\end{array}$} \\
\hline & & & & & & & & & & & & & & & & & \\
\hline & & & & & & & & & & & & & & & & & \\
\hline X-STATIC & 379.93 & 8.206 & 9.392E-04 & 0.134 & $1.244 \mathrm{E}-06$ & 0.083 & 7.7E-07 & 1.568 & 1.709 & 1.603 & 1.63 & $1.508 \mathrm{E}-05$ & 0.073 & 4.50 & 1.61 & 8.25 & 5.11 \\
\hline PLASMA-NP & 419.64 & 0.164 & 1.873E-05 & 0.214 & $1.988 \mathrm{E}-06$ & 0.176 & 1.63E-06 & 0.320 & 0.359 & 0.356 & 0.34 & 3.194E-06 & 0.022 & 6.32 & 17.05 & 62.22 & 50.99 \\
\hline NP-PES surface & 1943 & 0.056 & 6.449E-06 & 0.039 & 3.616E-07 & 0.012 & $1.08 \mathrm{E}-07$ & 0.262 & 0.261 & 0.207 & 0.24 & $2.257 \mathrm{E}-06$ & 0.031 & 12.87 & 34.99 & 16.02 & 4.81 \\
\hline NP-PES & 410.18 & 0.041 & 4.648E-06 & 0.001 & b.d.i. & -0.002 & b.d.i. & 0.011 & 0.010 & 0.012 & 0.01 & $9.734 \mathrm{E}-08$ & 0.001 & 9.52 & 2.09 & $<29.89$ & $<29.89$ \\
\hline NP-PES/PA & 404.6 & 0.098 & $1.121 \mathrm{E}-05$ & 0.002 & b.d.l. & -0.001 & b.d.i. & 0.042 & 0.029 & 0.042 & 0.04 & $3.492 \mathrm{E}-07$ & 0.007 & 19.35 & 3.12 & $<8.3$ & $<8.3$ \\
\hline AG KILL BACT & 415.2 & 1.104 & $1.264 \mathrm{E}-04$ & 0.149 & $1.383 \mathrm{E}-06$ & 0.047 & 4.37E-07 & 1.726 & 1.577 & 1.766 & 1.69 & $1.566 \mathrm{E}-05$ & 0.100 & 5.89 & 12.39 & 8.83 & 2.79 \\
\hline Blank 1 & & & & 0.000 & & -0.001 & & & & & & & & & & & \\
\hline Blank 2 & & & & -0.001 & & -0.001 & & & & & & & & & & & \\
\hline
\end{tabular}


Appendix F -Textile washing- ${ }^{\text {st }}$ cycle. B.d.I (below detection limit of ICP-OES $=2.87 \cdot 10^{-8} \mathrm{M}$ )

$\%$ of total Ag released

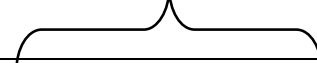

\begin{tabular}{|c|c|c|c|c|c|c|c|c|c|c|c|c|c|c|c|c|c|}
\hline Textile ID & Textile Mass & $\begin{array}{c}\mathrm{Ag} \\
\text { content }\end{array}$ & $\begin{array}{l}\text { Total Ag } \\
\text { in the } \\
\text { system }\end{array}$ & $\begin{array}{c}\mathrm{Ag}<450 \\
\mathrm{~nm} \\
\text { (filtered) }\end{array}$ & $\begin{array}{c}\mathrm{Ag}<450 \\
\mathrm{~nm} \\
\text { (filtered) }\end{array}$ & $\begin{array}{c}\mathrm{Ag} \\
\text { dissolved } \\
\text { (filt./centr.) }\end{array}$ & $\begin{array}{c}\text { Ag } \\
\text { dissolved } \\
\text { (filt./centr.) }\end{array}$ & $\begin{array}{l}\text { Total } \\
\mathbf{A g} \\
\text { release }\end{array}$ & $\begin{array}{l}\text { Total } \\
\mathrm{Ag} \\
\text { release }\end{array}$ & $\begin{array}{l}\text { Total } \\
\mathbf{A g} \\
\text { release }\end{array}$ & $\begin{array}{l}\text { Total } \\
\text { Ag } \\
\text { release } \\
\text { (mean) }\end{array}$ & $\begin{array}{l}\text { Total Ag } \\
\text { release } \\
\text { (mean) }\end{array}$ & $\begin{array}{c}\text { STDV } \\
\text { total } \\
\text { Ag } \\
\text { release }\end{array}$ & $\begin{array}{c}\text { STDV } \\
\text { total } \\
\mathbf{A g} \\
\text { release }\end{array}$ & $\begin{array}{l}\text { Total Ag } \\
\text { released }\end{array}$ & $\begin{array}{c}\mathrm{Ag}<450 \\
\mathrm{~nm}\end{array}$ & $\begin{array}{l}\text { Dissolved } \\
\text { Ag }\end{array}$ \\
\hline & mg & mg & Molarity & $\mathrm{mg} / \mathrm{L}$ & Molarity & $\mathrm{mg} / \mathrm{L}$ & Molarity & $\mathrm{mg} / \mathrm{L}$ & $\mathrm{mg} / \mathrm{L}$ & $\mathrm{mg} / \mathrm{L}$ & $\mathrm{mg} / \mathrm{L}$ & Molarity & $\mathrm{mg} / \mathrm{L}$ & $\%$ & $\%$ & $\%$ & $\%$ \\
\hline & & & & & & & & $\begin{array}{c}\text { 1st } \\
\text { aliquot }\end{array}$ & $\begin{array}{l}\text { 2nd } \\
\text { aliquot }\end{array}$ & $\begin{array}{c}\text { 3rd } \\
\text { aliquot }\end{array}$ & & & & & & & \\
\hline X-STATIC & 403.75 & 8.721 & $9.981 \mathrm{E}-04$ & 0.1277 & $1.184 \mathrm{E}-06$ & 0.08525 & $7.9 \mathrm{E}-07$ & 1.4398 & 1.7560 & 1.5035 & 1.5664 & $1.4522 \mathrm{E}-05$ & 0.1672 & 10.68 & 1.45 & 8.15 & 5.44 \\
\hline AGCL & 2218.34 & 0.018 & $2.031 \mathrm{E}-06$ & 0.011 & $1.017 \mathrm{E}-07$ & 0.0029 & b.d.i. & 0.0700 & 0.0673 & 0.0833 & 0.0735 & $6.8139 \mathrm{E}-07$ & 0.0086 & 11.64 & 33.55 & 14.93 & $<4.2$ \\
\hline $\begin{array}{c}\text { AGCL } \\
\text { BINDER }\end{array}$ & 2218.65 & 0.027 & 3.047E-06 & 0.0163 & $1.513 \mathrm{E}-07$ & 0.0011 & b.d.i. & 0.0595 & 0.0730 & 0.0628 & 0.0651 & $6.0336 \mathrm{E}-07$ & 0.0070 & 10.83 & 19.80 & 25.08 & $<4.7$ \\
\hline NP-PES/PA & 399.3 & 0.097 & 1.106E-05 & 0.0039 & $3.639 \mathrm{E}-08$ & -0.0004 & b.d.i. & 0.0190 & 0.0218 & 0.0223 & 0.0210 & $1.9468 \mathrm{E}-07$ & 0.0018 & 8.33 & 1.76 & 18.69 & $<14.7$ \\
\hline $\begin{array}{c}\text { AG KILL } \\
\text { BACT }\end{array}$ & 417.18 & 1.110 & 1.270E-04 & 0.1398 & 1.296E-06 & 0.0388 & 3.6E-07 & 1.9193 & 1.9653 & 1.9485 & 1.9443 & $1.8025 \mathrm{E}-05$ & 0.0233 & 1.20 & 14.19 & 7.19 & 2.00 \\
\hline Blank 1 & & & & 0.0003 & & -0.0002 & & -0.0005 & & & & & & & & & \\
\hline Blank 2 & & & & -0.0002 & & -0.0001 & & 0.003 & & & & & & & & & \\
\hline
\end{tabular}


Appendix G-Textile washing- $2^{\text {nd }}$ cycle. B.d.I (below detection limit of ICP-OES $=2.87 \cdot 10^{-8} \mathrm{M}$ )

\begin{tabular}{|c|c|c|c|c|c|c|c|c|c|c|c|c|c|c|}
\hline \multirow[t]{3}{*}{ Textile ID } & $\begin{array}{c}\mathrm{Ag}<450 \\
\mathrm{~nm} \\
\text { (filtered) }\end{array}$ & $\begin{array}{c}\mathrm{Ag}<450 \\
\mathrm{~nm} \\
\text { (filtered) }\end{array}$ & $\begin{array}{c}A g \\
\text { dissolved } \\
\text { (filt./centr.) }\end{array}$ & $\begin{array}{c}\mathrm{Ag} \\
\text { dissolved } \\
\text { (filt./centr.) }\end{array}$ & $\begin{array}{l}\text { Total } \\
\mathrm{Ag} \\
\text { release }\end{array}$ & $\begin{array}{l}\text { Total } \\
\mathrm{Ag} \\
\text { release }\end{array}$ & $\begin{array}{l}\text { Total } \\
\mathrm{Ag} \\
\text { release }\end{array}$ & $\begin{array}{l}\text { Total } \\
\text { Ag } \\
\text { release } \\
\text { (mean) }\end{array}$ & $\begin{array}{c}\text { Total Ag } \\
\text { release } \\
\text { (mean) }\end{array}$ & $\begin{array}{c}\text { STDV } \\
\text { total } \\
\mathrm{Ag} \\
\text { release }\end{array}$ & $\begin{array}{c}\text { STDV } \\
\text { total } \\
\mathbf{A g} \\
\text { release }\end{array}$ & $\begin{array}{l}\text { Total } \mathrm{Ag} \\
\text { released }\end{array}$ & $\begin{array}{c}\mathrm{Ag}<450 \\
\mathrm{~nm}\end{array}$ & $\begin{array}{c}\text { Dissolved } \\
\text { Ag }\end{array}$ \\
\hline & $\mathrm{mg} / \mathrm{L}$ & Molarity & $\mathrm{mg} / \mathrm{L}$ & Molarity & $\mathrm{mg} / \mathrm{L}$ & $\mathrm{mg} / \mathrm{L}$ & $\mathrm{mg} / \mathrm{L}$ & $\mathrm{mg} / \mathrm{L}$ & Molarity & $\mathrm{mg} / \mathrm{L}$ & $\%$ & $\%$ & $\%$ & $\%$ \\
\hline & & & & & $\begin{array}{c}\text { 1st } \\
\text { aliquot }\end{array}$ & $\begin{array}{l}\text { 2nd } \\
\text { aliquot }\end{array}$ & $\begin{array}{c}\text { 3rd } \\
\text { aliquot }\end{array}$ & & & & & & & \\
\hline X-STATIC & 0.037 & $3.425 \mathrm{E}-07$ & 0.01735 & $1.61 \mathrm{E}-07$ & 0.6275 & 0.6845 & 0.6188 & 0.6436 & 5.966E-06 & 0.036 & 5.55 & 0.60 & 5.74 & 2.70 \\
\hline AGCL & 0.0032 & b.d.I. & 0.00055 & b.d.i. & 0.0525 & 0.0448 & 0.0478 & 0.0483 & $4.481 \mathrm{E}-07$ & 0.004 & 8.08 & 22.06 & $<6.4$ & $<6.4$ \\
\hline AGCL BINDER & 0.0039 & 3.616E-08 & -0.0003 & b.d.i. & 0.0228 & 0.0223 & 0.0278 & 0.0243 & $2.248 \mathrm{E}-07$ & 0.003 & 12.54 & 7.38 & 16.08 & 12.7 \\
\hline NP-PES & 0.0004 & b.d.i. & -0.00015 & b.d.i. & 0.0003 & 0.0028 & 0.0023 & 0.0018 & b.d.i. & 0.001 & 75.59 & $<100$ & $<100$ & $<100$ \\
\hline NP-PES/PA & 0.0016 & b.d.i. & 0.00005 & b.d.i. & 0.0088 & 0.0058 & 0.0098 & 0.0081 & 7.494E-08 & 0.002 & 25.75 & 0.678 & $<38.3$ & $<38.3$ \\
\hline AG KILL BACT & 0.0893 & 8.274E-07 & 0.0394 & 3.65E-07 & 0.5160 & 0.5208 & 0.5070 & 0.5146 & 4.770E-06 & 0.007 & 1.36 & 3.76 & 17.34 & 7.66 \\
\hline Blank 1 & 0.0002 & & 0.00045 & & -0.0015 & & & & & & & & & \\
\hline Blank 2 & 0.0002 & & -0.00005 & & 0.00125 & & & & & & & & & \\
\hline
\end{tabular}


Appendix H -Textile washing- "Bleach" cycle. B.d.I (below detection limit of ICP-OES $=2.87 \cdot 10^{-8} \mathrm{M}$ )

\begin{tabular}{|c|c|c|c|c|c|c|c|c|c|c|c|c|c|c|c|c|c|}
\hline \multirow[t]{3}{*}{ Textile ID } & \multirow{3}{*}{$\begin{array}{c}\text { Textile } \\
\text { Mass } \\
\text { mg }\end{array}$} & \multirow{3}{*}{$\begin{array}{c}\text { Perborate } \\
\text { tetrahydrate } \\
\text { added } \\
\\
\text { mg }\end{array}$} & \multirow{3}{*}{$\begin{array}{l}\text { Total Ag } \\
\text { in the } \\
\text { system }\end{array}$} & \multirow{3}{*}{$\begin{array}{c}\mathrm{Ag}<450 \\
\mathrm{~nm} \\
\text { (filtered) } \\
\\
\mathrm{mg} / \mathrm{L}\end{array}$} & \multirow{3}{*}{$\begin{array}{c}\begin{array}{c}\mathrm{Ag}<450 \\
\mathrm{~nm}\end{array} \\
\text { (filtered) } \\
\\
\text { Molarity }\end{array}$} & \multirow{3}{*}{$\begin{array}{c}\text { Ag } \\
\text { dissolved } \\
\text { (filt./centr.) } \\
\text { mg/L }\end{array}$} & \multirow{3}{*}{$\begin{array}{c}\text { Ag } \\
\text { dissolved } \\
\text { (filt./centr.) } \\
\text { Molarity }\end{array}$} & \multirow{3}{*}{$\begin{array}{c}\begin{array}{c}\text { Total } \\
\text { Ag }\end{array} \\
\text { release }\end{array}$} & \multirow{3}{*}{$\begin{array}{c}\begin{array}{c}\text { Total } \\
\text { Ag }\end{array} \\
\text { release }\end{array}$} & \multirow{3}{*}{$\begin{array}{c}\begin{array}{c}\text { Total } \\
\mathrm{Ag} \\
\text { release }\end{array} \\
\mathrm{mg} / \mathrm{L} \\
\begin{array}{l}3 \mathrm{rd} \\
\text { aliquot }\end{array}\end{array}$} & \multirow{3}{*}{$\begin{array}{c}\begin{array}{c}\text { Total } \\
\mathrm{Ag} \\
\text { release } \\
\text { (mean) }\end{array} \\
\\
\mathrm{mg} / \mathrm{L}\end{array}$} & \multirow{3}{*}{$\begin{array}{l}\text { Total Ag } \\
\text { release } \\
\text { (mean) } \\
\text { Molarity }\end{array}$} & \multirow{3}{*}{$\begin{array}{c}\text { STDV } \\
\text { total } \\
A g \\
\text { release } \\
\\
\\
\mathrm{mg} / \mathrm{L}\end{array}$} & \multirow{3}{*}{$\begin{array}{c}\text { STDV } \\
\text { total } \\
\mathrm{Ag} \\
\text { release } \\
\\
\\
\%\end{array}$} & \multirow{3}{*}{$\begin{array}{c}\text { Total Ag } \\
\text { released }\end{array}$} & \multirow{3}{*}{$\begin{array}{c}\underset{\mathrm{nm}}{\mathrm{Ag}}<450 \\
\quad \%\end{array}$} & \multirow{3}{*}{$\begin{array}{l}\text { Dissolved } \\
\quad \text { Ag } \\
\\
\quad \%\end{array}$} \\
\hline & & & & & & & & & & & & & & & & & \\
\hline & & & & & & & & & & & & & & & & & \\
\hline X-STATIC & 399.05 & 81.6 & $9.865 \mathrm{E}-04$ & 0.1164 & $1.079 \mathrm{E}-06$ & 0.06065 & $5.62 \mathrm{E}-07$ & 0.7395 & 0.9725 & 0.8345 & 0.8488 & 7.8692E-06 & 0.1171 & 13.80 & 0.80 & 13.71 & 7.14 \\
\hline AGCL & 2069.13 & 81.16 & $1.895 \mathrm{E}-06$ & 0.0079 & 7.347E-08 & 0.0022 & b.d.i. & 0.0788 & 0.1095 & 0.0875 & 0.0919 & $8.5212 \mathrm{E}-07$ & 0.0158 & 17.24 & 44.98 & 8.62 & $<3.3$ \\
\hline AGCL BINDER & 2083.93 & 81.75 & 2.862E-06 & 0.0119 & $1.106 \mathrm{E}-07$ & -0.00045 & b.d.i. & 0.0853 & 0.0800 & 0.0785 & 0.0813 & 7.5323E-07 & 0.0035 & 4.36 & 26.32 & 14.68 & $<3.8$ \\
\hline NP-PES & 406.5 & 80.95 & $4.606 \mathrm{E}-06$ & 0.0003 & b.d.i. & 0.0004 & b.d.i. & 0.0135 & 0.0130 & 0.0135 & 0.0133 & $1.2361 \mathrm{E}-07$ & 0.0003 & 2.16 & 2.68 & $<23.2$ & $<23.2$ \\
\hline NP-PES/PA & 404.9 & 80.89 & $1.121 \mathrm{E}-05$ & 0.0025 & b.d.i. & 0.0006 & b.d.i. & 0.0658 & 0.0395 & 0.0483 & 0.0512 & 4.7434E-07 & 0.0133 & 26.12 & 4.23 & $<6.1$ & $<6.1$ \\
\hline AG KILL BACT & 396.68 & 81.83 & $1.208 \mathrm{E}-04$ & 0.1315 & $1.219 \mathrm{E}-06$ & 0.0365 & $3.38 \mathrm{E}-07$ & 0.9898 & 0.6525 & 1.0603 & 0.9008 & $8.3512 \mathrm{E}-06$ & 0.2179 & 24.19 & 6.91 & 14.59 & 4.05 \\
\hline Blank 1 & & 81 & & 0.0014 & & 0.0006 & & 0.00725 & & & & & & & & & \\
\hline Blank 2 & & 80.43 & & 0.0008 & & 0.0003 & & 0.008 & & & & & & & & & \\
\hline
\end{tabular}


Appendix I

A- washing machine

B- textile samples
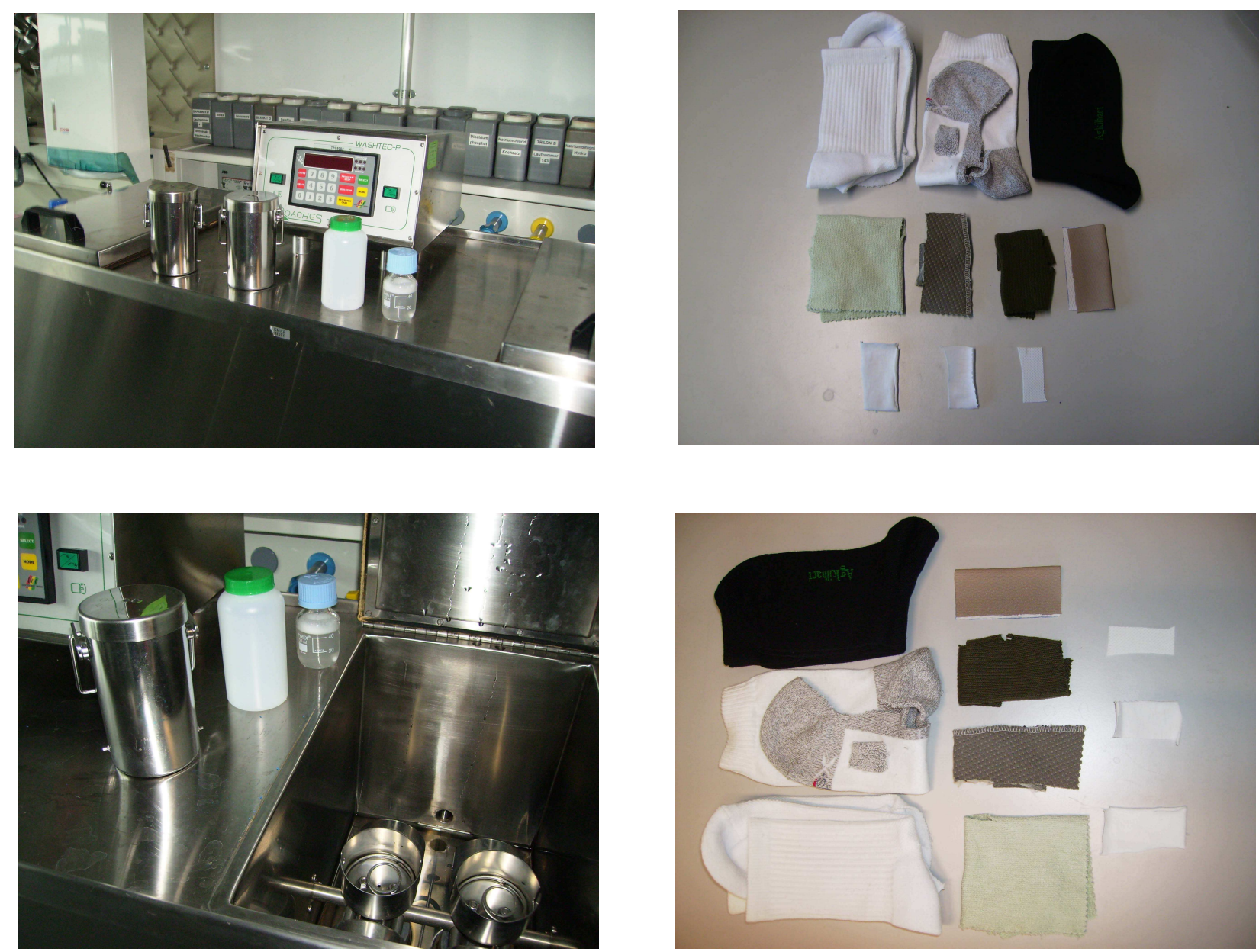

C- Ag-NP suspensions and ISE
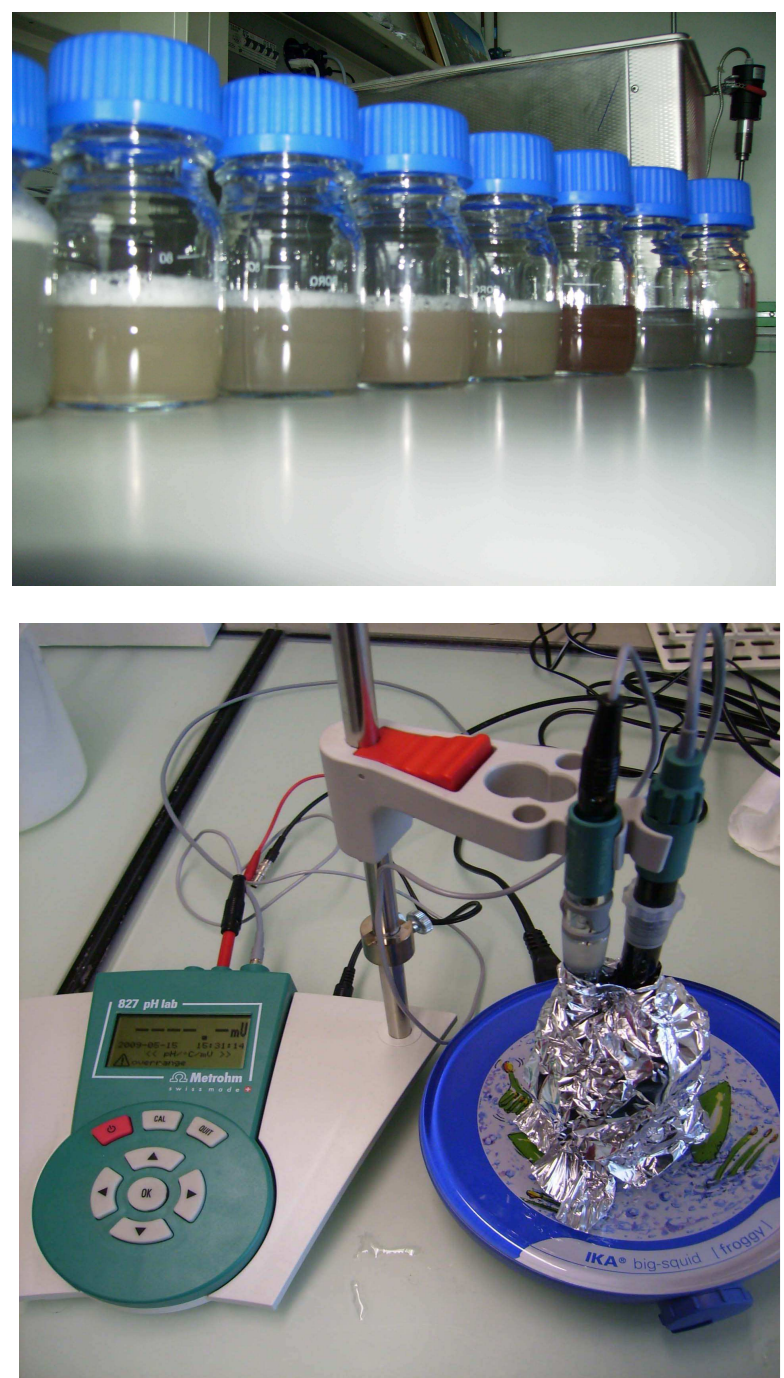
